\section{Türkiye'deki mevduat ve katılım bankalarının sosyal medya kullanımı: İnstagram değerlendirme endeksi ile karşılaştırmalı bir çalışma}

\author{
Social media usage of deposits and participation banks in Turkey: A \\ comparative study with the Instagram assessment index
}

\author{
Ceylan Bozpolat ${ }^{1}$ \\ Efe Duran ${ }^{2}$ \\ Öz
}

${ }^{1}$ Dr. Öğr. Üyesi, Nevşehir Hacı Bektaş Veli Üniversitesi İktisadi ve İdari Bilimler Fakültesi, Nevşehir, Türkiye, cakdogan@nevsehir.edu.tr

ORCID: 0000-0002-9672-8308

${ }^{2}$ Yüksek Lisans Öğrencisi, Nevşehir Hac1 Bektaş Veli Üniversitesi Sosyal Bilimler Enstitüsü, Nevşehir, Türkiye, eefeduran@gmail.com

ORCID: 0000-0002-2336-3969

\section{Sorumlu Yazar/Corresponding Author:}

Ceylan Bozpolat,

Nevşehir Hacı Bektaş Veli Üniversitesi, Nevşehir, Türkiye,

cakdogan@nevsehir.edu.tr

Başvuru/Submitted: 2/04/2021

Revizyon/Revised: 20/05/2021

Kabul/Accepted: 25/05/2021

Yayın/Online Published: 25/06/ 2021

Atıf/Citation: Bozpolat, C., \& Duran, E., Türkiye'deki mevduat ve katılım bankalarının sosyal medya kullanımı: İnstagram değerlendirme endeksi ile karşılaştırmalı bir çalışma, bmij (2021) 9 (2): 579-602, doi: https://doi.org/10.15295/bmij.v9i2.1807
Günümüzde bankalar, mevcut ve potansiyel müsterileri ile interaktif olarak iletișimde olma, onların ihtiyaçlarını tanımlama ve bu ihtiyaçlara uygun ürün ve hizmetler ile ilgili reklam yapma gibi amaçlarla sosyal medyayı pazarlama stratejilerinde bir araç olarak kullanmaktadır. Bu çalıșmanın amacı, Türkiye' deki mevduat ve katılım bankalarının Instagram kullanımlarını müşteri ilişkileri ve pazarlama yönetimi perspektifinde değerlendirmektir. Bu bağlamda çalışmada, Miranda vd. (2013) tarafından geliştirilen Facebook Değerlendirme Endeksi (FAI) kapsam geçerlilik analizi yapılarak Instagram özelinde uyarlanmıștır. Popülerlik, etkileșim ve içerik olmak üzere üç parametrede değerlendirilen bu endeks aracılığıyla bankaların Instagram kullanımları nicel olarak karşılaştırılmıştır. Parametrelere ilişkin veriler içerik analizi yöntemi ile elde edilmiştir. Bu yöntem, ilgili bankaların Instagram hesaplarından alınan halka açık verilerin değerlendirilmesine dayanmaktadır. Sonuçlar Türkiye'deki bankaların 2015 ve öncesi döneme göre Instagram kullanımlarının artığını ancak bu bankaların sadece \%36,7'sinin Instagram'ı müşteri etkileşimlerinde etkin bir şekilde kullandığını göstermektedir. Ayrıca etkin Instagram kullanımında takipçi sayısının tek başına yeterli olmadığı aynı zamanda paylaşılan gönderilerin içeriği ve bu gönderilere iletilen müşteri geribildirimlerinin de önemli bir yere sahip olduğu tespit edilmiştir. Çalışma sonuçları bankalara Instagram kullanımlarını rakipleri ile karşılaştırma imkânı tanıyarak sosyal medya pazarlamasında Instagram'ın geleceğine yönelik ipuçları sunmaktadır. Ek olarak çalışma, sosyal meyda pazarlaması araçlarından Instagram'ın sektörel bazlı kullanımına ilişkin veriler sunması bakımından literatüre katkı sağlamaktadır.

Anahtar Kelimeler: Bankacilık Sektörü, Sosyal Medya, Instagram Değerlendirme Endeksi

Jel Kodları: G21, M31, M37

\begin{abstract}
Today, banks use social media as a tool in their marketing strategies to interactively communicate with their existing and potential customers, identifying their needs and advertising products and services appropriate to these needs. This study aims to evaluate Instagram use of the deposit and participation banks from customer relations and marketing management in Turkey. In this context, Miranda et al. (2013) Facebook Assessment Index (FAI) developed by was explicitly adapted for Instagram by performing a content validity analysis. With this index, which is evaluated in three parameters: popularity, interactivity and content, the use of Instagram by banks was quantitatively compared. The data relating to the parameters were obtained by the content analysis method. This method is based on the evaluation of public data taken from the Instagram accounts of the relevant banks. Results show that increasing use of Instagram of banks compared to 2015 and before in Turkey, but only $36.7 \%$ of these banks effectively use in customer interaction Instagram. In addition, it has been determined that the number of followers is not sufficient by itself in the effective use of Instagram, and the content of the shared posts and the customer feedback conveyed to these posts have an essential place. The study results provide clues for the future of Instagram in social media marketing by allowing banks to compare their Instagram usage with their competitors. In addition, the study contributes to the literature in terms of providing data on the use of Instagram, one of the social media marketing tools, on a sectoral basis.
\end{abstract}

Keywords: Banking Sector, Social Media, Instagram Assessment Index

Jel Codes: G21, M31, M37 


\section{Extended Abstract}

\section{Social media usage of deposits and participation banks in Turkey: A comparative study with the Instagram assessment index}

\section{Literature}

With the increase in the number of social media platforms such as Instagram, Twitter and Facebook, as in many other sectors, these platforms have started to be used as a marketing and communication channel in the banking sector. Financial service providers make use of social networking sites to quickly share information on many issues such as loans, interest rates, payment plans, credit cards, corporate social responsibility projects, and to be in two-way communication with customers (Işık et al.2017) and to offer C2C communication environment to customers unlike traditional mass media (Stone, 2009). All these advantages of social media affect customer loyalty in the long term (Mousavi et al., 2015; K1lıç, 2017; Ajina, 2019), increase the behaviour of consumers concerning market performance to the extent that they will provide profit for the company (Chung et al., 2014) and increases its competitive power providing cost advantage. (Nyambu, 2013; Arıkan, 2015). Despite all these advantages of social media, many banks in the sector are still sceptical about the reliability of social media platforms and the compliance of their security standards with the bank system infrastructure (Mitic and Kapoulas, 2012). There is a need for in-depth research to reduce this suspicion and promote social media as a strategic tool in bank marketing. To address this need and to determine the relationship between social media and financial behaviour, a study was carried out by ING Group and concluded that $51 \%$ of young people in Turkey expect to make their payments via social media (www.ing.com.tr/ 2020). Deniz et al. (2018) stated in their study that banks that offer online banking services via social media accounts are more effective than banks that do not have banking activities on social media. On the other hand, in a study comparing the financial performances of banks using Facebook and those that do not, it was concluded that there was no statistically significant relationship between Facebook use and return on assets and equity (Malhatro, 2017). However, Konak and Demir (2018) found that the use of Facebook hurt the performance of the banks operating in Turkey and Twitter had a positive effect.

\section{Research subject}

This study evaluates the Instagram usage of deposit and participation banks in Turkey from customer relations and marketing management.

\section{Research purpose and importance}

The research aims to reveal the levels of Instagram usage of deposit and participation banks in Turkey. Besides, it also aims to determine the positions of banks and their competitors in Instagram with the help of an adapted index. Since there is not enough research in this regard, the current study is essential in providing the sector with an index to evaluate their social network usage levels and be a source of literature.

\section{Contribution of the article to the literature}

The positive and negative results of the use of social media by banks indicated in the literature title reveal that the role of social media in banking services has not yet become apparent. Also, most of the work focuses on Facebook and Twitter, which has led to a comprehensive analysis of Instagram, which has an increasing number of users and commercial quality in the world, specifically for banks. Although many studies are examining the use of Instagram for marketing purposes in commodity markets (Ginsberg, 2015; Vassallo et al., 2018), there are limited studies on Instagram by financial service providers (Al-Kandari et al., 2019; Ramadawati et al., 2019). In this context, this study, which assesses the use of Instagram by businesses in the banking industry in detail, offers clues to the future of Instagram in social media marketing.

\section{Design and method}

\section{Research type}

The Qualitative Research Method was used in the study. A total of 30 banks, including three public deposit banks (KMB), six participation banks (KB), eight private deposit banks (CPC) and 13 foreign deposit banks, were included in the study (YMB) (www.tbb.org.tr/ 2020). The data obtained from the official Instagram accounts of these banks were analysed within the framework of Instagram Rating index (IDE) parameters.

\section{Research problems}

The study aims to determine the Instagram usage levels of each bank in the research compared to other banks, both in and out of its category.

\section{Data collection method}

In the study, the Facebook Assessment Index (FAI) developed by Miranda et al. (2013) was explicitly adapted for Instagram by conducting a scope validity analysis. In this context, the opinions of 14 experts who provide training in the field of social media marketing online were taken through the expert evaluation form prepared by the researcher, and they were asked to state their opinions on the usability of the parameter criteria in the Facebook rating index specifically for Instagram as 1-Appropriate, 2must be adapted, 3- must be removed. As a result of the index analysis, "The number of likes for the page", which is the evaluation criterion for the popularity parameter, has been changed in line with the experts' opinions to the "number of followers". The evaluation criteria in the interaction parameter were accepted as they are. The 12 evaluation criteria of the content parameter have been removed from the final Instagram evaluation index because they do not meet the necessary conditions. As a result of the excluded criteria, the content validity of the index was found to be statistically significant. The data regarding the parameter criteria found to be significant were obtained from the official Instagram accounts of the banks by the documentary screening method. 


\section{Qualitative analysis}

Content analysis was used in the evaluation of the data obtained. In order to test the validity of the definitions of parameter criteria when conducting content analysis, the definitions were checked periodically by two well-trained experts (Kassarjian, 1977:9). The consistency between the researchers who made the criterion definitions shows the reliability of the study. In order to test reliability, a Kappa analysis should be performed that measures the consistency between researchers in parameter definitions (Kılıç, 2015: 142). In this study, Kappa analysis was not required, as a single researcher made the definitions.

\section{Findings and discussion}

\section{Findings as a result of analysis}

According to Instagram evaluation index scores, Halkbank in the public deposit bank category, Ziraat Katılım Bank in the public bank category, Türkiye İş Bank in the private deposit bank category and Garanti Bank in the foreign deposit bank category has the highest value score. It can be said that these banks use Instagram effectively and efficiently compared to other banks in their categories when their follower numbers, interactions with customers and content shares are evaluated. In the Uncategorized Bank ranking, it was observed that the bank that uses Instagram most effectively in Turkey is İş Bank with 88.36 IDE points; it is followed by Garanti Bank with 86.14 IDE points, Ziraat Katılım Bank with 82.47 IDE points, and Halkbank with 71.40 IDE points. For Halkbank to increase its place in Turkey's ranking, it needs to increase its popularity parameter score, in other words, the number of followers of its Instagram account. Compared to other banks in the ranking, it is seen that Halkbank has a small number of followers compared to these banks. It is making campaigns that will increase the number of followers that can allow the index score to rise.

Despite having the highest popularity and content value score in its category, Kuveyt Türk Participation Bank left its first place in Ziraat Participation Bank due to the low interaction value score. Having too many followers and constantly sharing content is not enough by itself in using Instagram as a tool to reach the target audience. Interaction with followers/customers has an essential place in effective Instagram use. Golden Global Bank Investment, ICBC Turkey Bank and Burgan Bank are the banks with the lowest index values in their category and Turkey's ranking. The index scores of these banks were low since they were not actively sharing on Instagram, the number of followers was low, and the lack of mutual interaction with customers.

\section{Discussing the findings with the literature}

Research results have shown that financial service providers use Instagram as a tool to reach the target audience. Contrary to the study results by Miranda et al. (2013) analysing the Facebook usage of 200 international banks, it was found in the present study that Garanti Bank is more active in using Instagram than other banks in its category. This finding is supported by the studies of Işık et al. (2017). The current study results are similar to the results of previous studies (Rubenwati et al., 2019; Tajvidi \& Karami, 2021), suggesting that social media can help promote banking products and services and improve direct relationships with customers. However, when the participation banks within the scope of the research are evaluated, it is seen that the Instagram interactions of the participation banks other than Ziraat Participation Bank are not sufficient. Banks in the participation Banking category, also known as Islamic banking, should use Instagram more effectively, allowing customer participation to reach potential customers and interact by receiving feedback from existing customers (Parveen et al., 2014).

\section{Conclusion, recommendation and limitations}

\section{Results of the article}

With the current study, an index was created to evaluate the use of Instagram by banks in Turkey, and results and comments on the parameters included in the index were presented. The fact that $75 \%$ of banks, which are first in their category in the popularity parameter, have more than 100,000 followers makes Instagram a virtual channel for communicating with the target audience. On the other hand, $10 \%$ of the banks covered by the research have under 1,000 followers. Of course, the number of followers alone is not enough to determine the levels of Instagram usage. Therefore, the interaction and content parameters of the banks should also be evaluated. In the context of the interaction parameter, the average number of messages that Banks shared, the number of likes of these messages, the number of comments, and the number of replies to comments were examined. Halk Bank (90), Ziraat Katılım Bank (88.88), Isbank of Turkey (86.11), and Garanti Bank of Turkey (88.75) are the banks that pay the most attention to bank-customer interaction in their categories. Although Vakıf Bank has a high number of posts and likes, it received a low value in the interaction parameter due to the low number of comments made to its posts and the low rate of responding to comments. In the context of the content parameter, it is fair to say that the highest-rated banks in their categories use multimedia elements to provide information about financial products and services, offer campaigns and special offers, announce social sensitivity activities, and use Instagram marketing tool in doing all this. After comparing the banks ' popularity, interaction and content parameters, the final Instagram rating index (IDE) results were presented. According to the index results, İş Bank has been the most successful bank in Turkey in communicating with the target audience via Instagram, with an index score of 88.36.

On the other hand, it has been determined that Golden Global Bank does not use Instagram as an effective means of communicating with the target audience. In addition, it was found that $36.7 \%$ of the banks subject to the analysis scored above 50 index points, $36.7 \%$ scored between $25-50$ and $26.6 \%$ between $3-25$. These results show that most of the banks $(63.3 \%)$ do not use Instagram effectively.

\section{Suggestions based on results}

Instagram is a powerful marketing tool for banks that want to do social media marketing. Social media platforms can drive consumer attitudes and behaviours by significantly expanding the domain of banks' products and services (Jashari and Rrustemi, 2017). In this direction, the development of strategies to increase the effectiveness of social media accounts is essential for the marketing activities of banks in the digital environment. Banks with little Instagram interaction should use Instagram to reach out to customers rather than imitating a competitor's move. The advantages of social media platforms, such as delivering content related to products and services to the target audience quickly and effectively, thereby providing an advantage in marketing and advertising costs, as well as keeping brand visibility up to date in the digital environment thanks to its flexibility, should be noted. It can be said that banks with high popularity value points have these advantages. However, to provide a sustainable advantage, 
the statistical information provided by the Instagram platform should be continuously evaluated, and future strategies should be determined accordingly.

Sharing frequently on Instagram is quite essential. The high number of likes, comments and shares on the account indicates that consumers see more of the shares made and that the bank interacts with consumers. However, each post must be a quality post. Sharing destructive content can cause an immediate reaction from consumers and a bad image of the bank. That is why keeping the sharing schedule consistent is essential for success. As a result of the reviews, it was observed that the popularity and interaction value scores of banks with a small number and insufficient content sharing were also low. Contests, gamification applications, posts with special offers allow for both effective content and increased follower count. The number of followers, which increased due to the content sharing, enables the bank to expand the target audience to convey its marketing messages and increase the interaction between the bank-customer and the customer-customer.

The current study provides tips to banks that want to exist effectively on Instagram. With these tips, banks can strengthen their communication and relationships with their customers by identifying their strengths and weaknesses compared to their competitors. In addition, high-quality content sharing can influence customers and enable them to make e-WOM an essential place in using Instagram as an effective marketing tool in the financial services industry. In this context, banks should constantly follow the updates on Instagram, a dynamic social network and adapt their strategies according to these updates.

\section{Limitations of the article}

Research is limited to the deposit and participation banks operating in Turkey. Although it is categorically within the scope of the research subject, nine banks that cannot be evaluated either because they do not have an Instagram account or do not share anything despite having an account were not included in the study. Future research can compare the marketing use of Facebook and Instagram in different sectors with these indices developed.

\section{Giriş}


Tüm dünyanın dijital verilerini içeren ve bu verilere ilişkin güncel tablolar sunan We Are Social Digital Report 2020'ye göre, internet ve aktif sosyal medya kullanıcılarında önceki yıllara göre büyük oranda artış yaşanmaktadır. We Are Social Digital Turkey 2020 raporunda ise, sosyal medya platformları kullanıcı sayısına göre siralanmış ve YouTube, Instagram, Whatsapp, Facebook, Twitter platformlarının Türkiye'de en sık kullanılan sosyal medya platformları olarak yerini aldığı görülmüştür. Instagram özelinde ülke bazlı erişim sıralamasına bakıldığında Türkiye beşinci sırada yer almaktadır (www.wearesocial.com, 2020). Tüm bu bilgiler, Türkiye'de Instagram'ın yükselmeye ve popülerleşmeye devam ettiğinin bir göstergesidir. Bu yükseliş birçok sektörde olduğu gibi bankacillk sektöründe de fırsatlar yaratmaktadır. Dijitalleşme, finansal ürün ve hizmetleri sosyal medya gibi çevrimiçi ortamlarda kolay ve hızlı bir şekilde tanıtmaya olanak sağlamıştır. Ayrıca sosyal medya platformları üzerinden mevcut ve/veya potansiyel müşteriler ile kurulan çift yönlü iletişim, müşteri memnuniyetini artırmakta ve bankaların sektördeki konumunu güçlendirmektedir (Gu ve Ye, 2014; Ramanathan, Subramanian ve Parrott, 2017). Başka bir ifadeyle işletmelerin sosyal medya platformları üzerinden pazarlama ve markalaşma faaliyetleri yapmaları, performanslarını ve sürdürülebilirliklerini olumlu yönde etkilemektedir (Tajvidi ve Karami, 2021).

Tüm bu olumlu gelişmelere rağmen bankacıllk sektöründeki işletmelerin Instagram'daki yeri çok eski değildir. 2010-2015 yılları arasında sosyal medya kullanan 30 bankanın sadece \%10,3'ü Instagram hesabına sahipken (Göğüş, 2015), 2016-2020 yılları arasında sosyal medya kullanan banka sayısı 40'a çıkmış ve yüzdesel olarak bankaların Instagram kullanım oranı \%82,5'e yükselmiştir. Katılım ve kamu mevduat bankası kategorilerindeki bankaların tümü 2010-2015 yılları arasında resmi Instagram hesabına sahip değilken 2016-2020 yılları arasında bu bankaların tamamı resmi Instagram hesabı almıştır. Özel mevduat bankaları kategorisinde 2010-2015 yılları arasında Instagram kullanan banka sayısı 1 iken 20162020 yılları arasında bu sayının 8'e yükseldiği gözlemlenmiştir. Benzer bir şekilde yabancı mevduat bankaları kategorisinde ilgili periyotlarda Instagram hesabı olan banka sayısı 2' den 16'ya yükselmiştir. Toplamda 2010-2015 yılları arasında Instagram kullanan banka sayısı 3 iken bu sayı 2016-2020 yılları arasında 11 kat artarak 33'e yükselmiştir. Facebook, Twitter, YouTube, Linkedin ve Google Plus sosyal medya platformları ile karşılaştırıldığında ilgili dönem ve bankalar özelinde kullanım sayısı ve yüzdesi en yüksek artış gösteren sosyal medya platformu Instagram olmuştur. ${ }^{1}$

Instagram vb. sosyal medya platformlarının, geleneksel iletişim araçlarına kıyasla daha düşük bütçeli olma ve eşzamanlı olarak nihai tüketici ile doğrudan temasa izin verme gibi avantalara sahip olması (Kaplan ve Haenlein, 2010: 67) bu platformu, bankaların tutundurma stratejilerinde kullanılabilecek önemli bir araç haline getirmiştir. Müşterilerin bankacıllk ürün ve hizmetleriyle ilgili geribildirimlerini zaman ve mekan kıstı olmadan iletebildikleri bu platform, bankaların müşterileriyle olan ilişkilerini geliştirerek müşteri memnuniyetinin artmasına (Aldaihani ve Ali, 2018) ve yaratıcı içeriklerle marka imajını güçlenmesine olanak tanımaktadır (Bhatti, Maraim ve Arif, 2017). Önceki araştırmalar, stratejilerinde sosyal medyaya yer veren işletmelerin daha başarılı olduğunu göstermiştir (Schniederjans, Cao ve Schniederjans, 2013; Tajvidi ve Karami, 2021). Dijital çağın gerisinde kalmak istemeyen bankalar, stratejilerini sosyal medya özelinde uyarlamalıdır. Bu bağlamda mevcut araştırma, bankaların Instagram kullanımlarını müşteri ilişkileri ve pazarlama yönetimi perspektiflerinden değerlendirmeyi ve uyarlanmış bir endeks aracılığıyla bankaların Instagram kullanımlarını analiz etmeyi hedeflemektedir. Çalışma ile ortaya konan Instagram Değerlendirme Endeksi (IDE), bankaların endüstrideki diğer bankalara kıyasla Instagram hesaplarının güçlü ve zayıf yönlerini keşfetmelerini sağlaması bakımından sektöre; sosyal medya pazarlama stratejilerinde hangi öğelerin daha etkili olduğu konusunda verdiği ipuçları açısından literatüre katkı sunmaktadır.

Çalışmanın sonraki bölümlerinde, bankaların sosyal medya kullanımlarını konu alan literatürdeki eserler irdelenmiş ve Instagram Değerlendirme Endeksi (IDE)'nin oluşturulmasına ilişkin bilgilere yer verilmiştir. Araştırma metodolojisi çerçevesinde bankaların sosyal medya kullanımları ve Instagram değerlendirme endeksi araştırmasına ilişkin bulgular ve yorumlar sunulmuştur. Çalışma, araştırmaya ilişkin sonuçlar ve önerilerle tamamlanmıştır.

\section{Literatür}

Instagram, Twitter, Facebook gibi sosyal medya platformlarının kullanıcı sayılarının artmasıyla birlikte birçok sektörde olduğu gibi bankacılık sektöründe de pazarlama ve iletişim kanalı olarak bu platformlar kullanılmaya başlanmıştır. Finansal hizmet sağlayıcıları; krediler, faiz oranları, ödeme planları, kredi kartları, kurumsal sosyal sorumluluk projeleri gibi birçok konuda hızı bir şekilde bilgi paylaşmak, geleneksel kitle iletişim araçlarının aksine müşterilerle çift yönlü iletişimde olmak ve müşterilere C2C

${ }^{1}$ 2016-2020 dönemi Instagram kullanımlarına ilişkin bilgiler, bankaların resmi web sitelerinde yayınladıkları resmi sosyal medya hesaplarının incelenmesi sonucu elde edilmiştir. 
iletişim ortamı sunmak için sosyal ağ sitelerinden yararlanmaktadır (Stone, 2009). Sosyal medya platformlarının sağladığı tüm bu avantajlar uzun vadede müşteri sadakatini de beraberinde getirmektedir (Mousavi, Rad, ve Asayesh 2015). Ajina (2019)'nın Suudi Arabistan bankacıllk sektöründe sosyal medya kullanımının müşteri sadakatine etkisini incelediği çalışmasında, sosyal medya etkileşiminin müşteri sadakatini etkilediği; sadakatin ise bankanın mali yapısını güçlendirdiği belirtilmiştir. Bezer bir şekilde Chung, Animesh, Han ve Pinsonneault (2014) sosyal medya kullanımının piyasa performansı ile önemli ölçüde ilişkili olduğunu ve tüketicilerin davranışlarını firmaya kar sağlayacak ölçüde arttığını tespit etmişlerdir. Öte yandan geleneksel pazarlama araçlarına kıyasla maliyet avantajı sağlayan sosyal medya, teknolojideki gelişmelerin bir sonucu olarak işletmelerin rekabet gücünü de artırmaktadır (Nyambu, 2013). Ancak günümüzde sosyal medyanın tüketici davranışları üzerindeki potansiyelinin farkına varan bankalar, etkin kullanıcı sayısına sahip sosyal medya platformlarının çoğunda pazarlama stratejilerini aktif bir şekilde yürütmektedir. Sosyal medya platformlarında artan bankalar arası rekabet, bankaları sosyal içeriklerinde farklılık yaratacak ve marka kişiliği oluşturacak stratejiler geliştirmeye zorlamaktadır. Sosyal medya platformlarında yaratılan marka kişiliği marka sadakatini olumlu yönde etkilemektedir. Bu nedenle mevcut müş̧erilerini korumak ve potansiyel müşterileri pazar payına dahil etmek isteyen bankalar, sosyal medya içeriklerini müşterileri istek ve ihtiyaçları ile uyumlu marka kişiliği özeliklerine dönüştürerek paylaşmalıdır (Garanti ve Kissi, 2019).

Pazarlama stratejilerinde sosyal medyayı bir araç olarak kullanmanın yukarıda sıralanan avantajlarına rağmen halen sektörde birçok banka, sosyal medya platformlarının güvenirliği ve bu platformların güvenlik standartlarının banka sistem alt yapısı ile uyumluluğu konusunda şüphe duymaktadır (Mitic ve Kapoulas, 2012). Bu şüpheyi azaltmak ve sosyal medyanın banka pazarlamasında stratejik bir araç olarak kullanımını yaygınlaştırmak için derinlemesine araştırma yapma ihtiyacı vardır. Bu ihtiyacı gidermek ve sosyal medya ile finansal davranış arasındaki ilişkiyi belirmek amacıyla ING Grup tarafından bir araştırma gerçekleştirilmiştir. Araştırmada Türkiye'deki gençlerin \%51'inin ödemelerini sosyal medya üzerinden yapmak gibi bir beklentilerinin olduğu, sosyal medya aracıllğıyla bankalarıyla iletişime geçen ve mobil bankacilık hizmetlerini kullanan kişilerin paralarının yönetimi konusunda kendilerini güvende hissettikleri sonucuna ulaşılmıştır. Ayrıca araştırmaya katılanların \%39'u banka hakkında genel bilgi almak, \%32'si şikâyette bulunmak, \%31'i ise yardım ve banka ile iletişime geçmek için sosyal medyayı kullandıklarını ifade etmişlerdir (www.ing.com.tr/ 2020). Deniz, Derici ve Kılıç (2018) sektöre ve alan yazınına katkı sağlamak amacıyla yabancı ve özel sermayeli mevduat bankalarının internet bankacılığı hizmetinin, sosyal medya hesapları üzerinden sunulup sunulmadığını inceleyerek bankaların etkinliğini ölçümlemişlerdir. Bulgular, sosyal medya hesabı üzerinden çevrimiçi bankacılık hizmeti sunan bankaların, sosyal medyada bankacılık faaliyetlerinde bulunmayan bankalara göre daha etkin olduğu göstermiştir. Ayrıca sosyal medya etkileşiminin mevduat bankalarının etkinliğini artırmada önemli bir kanal olduğu vurgulanmıştır.

Bir diğer çalışmada, Türkiye Bankalar Birliği'nin verilerine göre Türkiye'deki en büyük üç bankanın (Ziraat Bankası, İş Bankası, Garanti Bankası) resmi Facebook hesapları irdelenmiştir. Elde edilen bulgular çerçevesinde, Garanti Bankası' nın, başta sosyal medyanın çift yönlü iletişim sunma özelliği olmak üzere pek çok özelliğini diğer bankalara göre daha etkin kullandığı gözlemlenmiştir (Işık, Karaca, İspir, Çakı ve Yıldırım, 2017). Kılıç (2017) ise pazarlama faaliyetleri bağlamında BIST 30'da yer alan bankaların Twitter kullanımını tahlil etmiş ve bankaların imajlarını geliştirmek, ilişkilerini güçlendirmek, hedef kitleleriyle duygusal bir bağ yaratmak ve sadakati arttırmak amacıyla bu platformu kullandıklarını belirtmiştir. Arıkan (2015) bankacılık sektöründeki inovasyonlardan biri olan sosyal medyanın rekabet avantajı sağlamada önemli rol oynadığını ifade etmiştir. Öte yandan Hindistan'da Facebook kullanan ve kullanmayan bankaların finansal performanslarının karşılaştırıldığı çalışmada, Facebook kullanımı ile aktif ve öz sermaye karlılık oranları arasında istatistiksel olarak anlamlı bir ilişki bulunmadığı sonucuna varılmıştır (Malhatro, 2017). Bununla birlikte Konak ve Demir (2018) Türkiye'de faaliyet gösteren bankaların firma performansı üzerinde Facebook kullanımının negatif, Twitter'ın ise pozitif etkisi olduğunu tespit etmişlerdir.

Bankaların sosyal medya kullanımının yukarıda ifade edilen pozitif ve negatif çıtıları, bankacılık hizmetlerinde sosyal medyanın rolünün henüz netleşmediğini ortaya koymaktadır. Ayrıca çalışmaların çoğunun Facebook ve Twitter odağında gerçekleşmesi, dünyada kullanıcı sayısı ve ticari niteliği giderek artan Instagram' 'n bankalar özelinde kapsamlı bir şekilde incelenmesi gerekliliğini doğurmuştur. Mal piyasalarında Instagram'ın pazarlama amaçlı kullanımını inceleyen birçok çalışma olmasına rağmen (Ginsberg, 2015; Vassallo, Kelly, Zhang, Wang, Young ve Freeman 2018) finansal hizmet sağlayıcılarının Instagram kullanımına ilişkin sınırlı sayıda çalışma vardır (Al-Kandari, Gaither, Alfahad, Dashti ve Alsaber, 2019; Rahmawati, Dewi ve Ferdian, 2019). Bu bağlamda bankacılık endüstrisindeki işletmelerin 
Instagram kullanımları ayrıntılı olarak değerlendirilerek bu çevrimiçi iletişim kanalında rakiplere göre güçlü ve zayıf yönler tespit edilmelidir.

\section{Metodoloji}

\section{Araştırmanın amacı ve önemi}

Mevcut çalışmada, 200 uluslararası bankanın Facebook kullanımlarını analiz etmek amacıyla Miranda Chamorro, Rubio ve Morgado (2013) tarafından geliştirilen Facebook Değerlendirme Endeksi Instagram özelinde uyarlanarak kullanılmıştır. Facebook Değerlendirme Endeksinde; popülerlik, etkileşim ve içerik olmak üzere üç temel parametre ve bu parametreleri oluşturan sırasıyla 1,4 ve 22 alt kriter bulunmaktadır. Endeksin hesaplanmasına ilişkin detaylara bulgular bölümünde yer verilmiştir. Kapsam geçerliliği sonucu Instagram özelinde uyarlanan endekste bankaların Instagram kullanımları popülerlik, etkileşim ve içerik olmak üzere üç temel parametre ve sırasıyla 1,4,10 alt kriter ile analiz edilmiştir. Araştırma Türkiye'deki mevduat ve katılım bankalarının Instagram kullanım düzeylerini ortaya koymayı amaçlamaktadır. Ayrıca, uyarlanmış bir endeks yardımıyla bankaların ve rakiplerinin Instagram'daki konumlarını belirlemeyi hedeflemektedir. Bu konuda yeterli sayıda araştırma bulunmadığından mevcut çalışma literatüre kaynak teşkil edecek bir çalışma olmasının yanında sektöre sosyal ă̆ kullanım düzeylerini değerlendirebilecekleri bir endeks sunması bakımından önemlidir.

\section{Araştırmanın evreni}

Türkiye Bankalar Birliği verilerine göre 2020 yılı itibariyle Türkiye'de faaliyet gösteren mevduat ve katılım bankası sayısı 39'dur. Ancak araştırmaya 3'ü kamu mevduat bankası (KMB), 6'sı katılım bankası (KB), 8'i özel mevduat bankası (ÖMB) ve 13'ü yabancı mevduat bankası (YMB) olmak üzere toplam 30 banka dahil edilmiştir (www.tbb.org.tr/ 2020). 9 bankanın araştırma evrenine dahil edilememesinin sebebi, bu bankaların bazılarının Instagram hesaplarının olmaması, bazılarının ise Instagram hesabı olmasına rağmen hiçbir paylaşımda bulunmamasıdır.

\section{Veri toplama aracının geliştirilmesi}

Facebook değerlendirme endeksinde yer alan parametrelere ilişkin kriterlerin, bir Instagram hesabını/profilini değerlendirmede uygun parametreler ve kriterler olup olmadığını test etmek amacıyla kapsam geçerlilik analizi yapılmıştır. Bu bağlamda araştırmacı tarafından hazırlanan uzman değerlendirmesi formu aracılığıyla çevrimiçi ortamda sosyal medya pazarlaması alanında eğitimler veren 14 uzmandan görüş alınmış ve Facebook değerlendirme endeksinde yer alan parametre kriterlerinin Instagram özelinde kullanılabilirliğine ilişkin görüşlerini 1-Uygundur, 2-Uyarlanmalı, 3Çıkartılmalı olacak şekilde belirtmeleri istenmiştir. Uzman seçiminde alanda en az 5 yıl deneyime sahip olma kriteri göz önünde bulundurulurken yaş, cinsiyet ve eğitim gibi demografik değişkenler dikkate alınmamıştır. Lawshe (1975)'e göre kapsam geçerliliğinin belirlenmesinde en az 5, en fazla ise 40 uzman görüşünün olması yeterlidir (Yurdagül, 2005:2). Uzman görüşleri sonucunda değerlendirilen parametre kriterlerinin hangisinin Instagram değerlendirme endeksinde yer alıp almayacağına karar verilirken Kapsam Geçerlilik Oranı (KGO) dikkate alınmaktadır ve aşağıdaki formül ile hesaplanmaktadır (Lawshe, 1975):

$$
\text { Kapsam Geçerlilik Oranı }(K G O)=\left(n /\left(\frac{n}{2}\right)-1\right)
$$

Formülde; n: Uygun diyen uzman görüş sayısını, N: Toplam uzman görüş sayısını ifade etmektedir. Instagram değerlendirme endeksinin parametre kriterlerine ilişkin KGO değerleri $\leq 0$ olan içerik parametresine ilişkin 11 kriter Instagram değerlendirme endeksine dahil edilmemiştir (Yeşilyurt ve Çapraz, 2018: 259). KGO değerleri hesaplandıktan sonra sıfırdan büyük parametre kriterlerinin her birinin istatistiki olarak anlamlı olup olmadığını test etmek için Kapsam Geçerlik Ölçütü (KGÖ) tespit edilmelidir. Ayre ve Scally (2014), yaptıkları çeşitli hesaplamalar sonucunda $p=0,05$ anlamlılık düzeyinde farklı uzman sayılarına göre KGÖ değerlerini tablolaştırmışlardır (Yeşilyurt ve Çapraz, 2018: 257). Bu tabloya göre $\mathrm{p}=0,05$ anlamlılık düzeyinde 14 uzman için KGÖ değerinin 0,571 'dir. KGO değeri KGÖ değerinden küçük içerik parametresindeki bir kriter istatistiki olarak anlamlı olmamasından dolayı geçerliliği test edilen Instagram değerlendirme endeksinden çıkartılmıştır.

Çıkarılan kriterler sonucunda tüm endeksin kapsam geçerliliğinin istatistiki olarak anlamlı olup olmadığını belirleyebilmek için Kapsam Geçerlik İndeksi (KGI) değerinin hesaplanması gerekmektedir. KGI değeri ise ölçekte yer alan kriterlerin KGO değerlerinin ortalamasından elde edilmektedir. Instagram değerlendirme endeksi üç (3) parametreden oluştuğundan her parametre için ayrı ayrı KGİ değeri hesaplanmalıdır (Yeşilyurt ve Çapraz, 2018: 257). Hesaplamalar sonucunda sırasıyla popülerlik parametresinin KGİ değeri 1.00; etkileşim parametresinin 0,857; içerik parametresinin 0,813 olarak bulunmuştur. Parametrelerin nihai endeksteki ağırlıkları ise popülerlik \%25, etkileşim \% 40 , içerik \%35 
olmak üzere orijinal endekste olduğu gibi kabul edilmiştir. Parametrelerin endeksteki yüzdelerinin KGI değeri ise 0,760 olarak hesaplanmıştır. 12 kriter çıkarılan nihai Instagram değerlendirme endeksinin KGİ değeri 0,825 olarak hesaplanmıştır. KGİKGÖ olması endekste kalan parametre kriterlerinin kapsam geçerliğinin istatistiki olarak anlamlı olduğunu göstermektedir (Lawshe, 1975; Yeşilyurt ve Çapraz, 2018: 260; Yurdagül, 2005).

Kapsam Geçerliliği Analizi sonucunda 14 uzman tarafından değerlendirilen endeksin; popülerlik parametresi için değerlendirme kriteri olan "sayfanın beğenilme sayısı" uzmanların görüşleri doğrultusunda "takipçi sayısı" olarak değiştirilmiştir. Etkileşim parametresinde yer alan değerlendirme kriterleri olduğu gibi kabul edilmiştir. İçerik parametresinin ise 12 değerlendirme kriteri yukarıda ifade edilen gerekçelerden dolayı nihai Instagram değerlendirme endeksinden çıkartılmıştır. Tablo 1'de Instagram değerlendirme endeksini oluşturan parametreler ve parametre kriterleri ayrıntılı olarak verilmiştir.

Tablo 1. Instagram Değerlendirme Endeksi Parametreleri ve Kriterleri

\begin{tabular}{cll}
\hline Parametreler & \multicolumn{1}{c}{ Parametre Kriterleri } \\
\hline Popülerlik & Hesabın takipçi sayısı \\
\cline { 2 - 3 } & $\begin{array}{l}\text { Son } 7 \text { gün içinde banka tarafından paylaşılan duvar ileti sayısı } \\
\text { Son 10 iletinin ortalama beğeni sayısı }\end{array}$ \\
& Son 10 iletiye yapılan ortalama yorum sayısı \\
Etkileşim & Son 24 saat içerisinde ve son 10 ileti arasından banka tarafından cevaplanan ortalama \\
& kullanıcı yorum sayısı & \\
\cline { 2 - 3 } & Videolar & Ürün bilgileri \\
& Fotoğraflar & Kurumsal kimlik (logo) \\
& Pazarlama mesajları & Talep ve öneriler \\
& Etkinlikler & Sosyal duyarlılık etkinlikleri \\
& Kuponlar ve özel teklifler & Oyunlaştırma uyg./yarışmalar \\
\hline
\end{tabular}

Instagram değerlendirme endeks puanı Tablo 1'de gösterilen parametrelerin değer puanlarının ağırlıklı toplamıdır. Başka bir ifadeyle her bankanın Instagram değerlendirme endeksi, ilgili bankanın popülerlik değer puanının (pdp) \%25'i, etkileşim değer puanının (edp) \%40'1 ve içerik değer puanının (idp) \%35'inin toplamından oluşmaktadır. Instagram değerlendirme endeksini aşağıdaki gibi formülize etmek mümkündür:

$$
\text { Instagram Değerlendirme Endeksi }=\left(\operatorname{pdp} \times \frac{25}{100}\right)+\left(\operatorname{edp} \times \frac{40}{100}\right)+\left(\operatorname{idp} \times \frac{35}{100}\right)
$$

Popülerlik parametresi, Instagram kullanıcılarının bankaların Instagram hesaplarına olan ilgilerini ölçmeye yönelik değeri içermektedir. Popülerlik değer puanı, "hesabın takipçi sayısı" ile belirlenmektedir. Etkileşim parametresi, bankalar ile bankaların Instagram hesaplarını takip eden kullanıcılar arasındaki etkileşim düzeyini ölçmeye yönelik değerleri içermektedir. Etkileşim parametresi, Tablo 1'de gösterilen parametre kriterlerinden oluşmaktadır. Etkileşim değer puanı, bu dört değerin her banka için ayrı ayrı aritmetik ortalamasının hesaplanması ile belirlenmektedir. İçerik parametresi, bankaların ürün ve hizmetlerini pazarlamada kullandıkları yöntemleri ve takipçileri üzerindeki etkilerini ölçmeye yönelik değerlerden oluşmaktadır. İçerik değer puanı, Tablo 1'de gösterilen on değerin, her banka için ayrı ayrı aritmetik ortalamasının hesaplanmasıyla bulunmaktadır (Miranda vd., 2013: 8-9).

\section{Verilerin toplanmasi}

Araştırma verilerinin toplanmasında, birincil kaynaklardan faydalanılmıştır. Toplanan veriler halka açık yayınlandığı için etik kurul izin onayı gerekmemektedir. BDDK ile TBB'nin web sitesi ve yayınlarından Türkiye'de faaliyet gösteren mevduat ve katılım bankalarının iletişim bilgilerine ulaşılmıştır. Ulaşılan bilgiler ile bankaların resmî web sitelerine, buradan da bankaların web siteleri aracılığıyla yayınladıkları resmi Instagram hesaplarına erişilmiştir. Instagram dinamik bir sosyal medya platformudur. Bu nedenle araştırma verileri 31 Mart 2020 ve öncesi dönemi kapsamaktadır. İlgili dönemde araştırmaya dahil edilen bankaların resmi Instagram hesaplarından, belgesel tarama yöntemi ile veri toplama işlemi gerçekleştirilmiştir. Nitel veri toplama yöntemlerinden biri olan belgesel tarama yöntemi, var olan kayıt ve belgeleri inceleyerek veri toplama olarak tanımlanmaktadır. Başka bir ifadeyle belgesel tarama, belli bir amaca dönük olarak, kaynakları bulma, okuma, not alma ve değerlendirme işlemlerini kapsamaktadır (Bowen, 2009). Kapsam geçerlilik analizi sonucunda geliştirilen endeksteki parametreleri oluşturan kriterlerin (Tablo 1) bankaların Instagram hesaplarında ne sıklıkta kullanıldığı içerik analizi yapılarak incelenmiştir. İçerik analizi, toplanan verilerin belirli bir amaç bakımından sınıflandırılması, özetlenmesi, belirli değişken veya kavramların ölçülmesi ve anlam 
çıkarılması için ön çalışma yaparak kategorilere ayrılması olarak tanımlanmaktadır (Tavşancıl ve Aslan, 2001: 85). İçerik analizi ile bankaların Instagram değerlendirme endeks parametre verileri (popülerlik, etkileşim ve içerik) ayrıntılı olarak incelenmiştir. İçerik analizi yaparken parametre kriterlerine ilişkin tanımlamaların geçerliğini test etmek amacıyla tanımlamalar, iyi eğitimli iki uzman tarafından düzenli aralıklarla kontrol edilmiştir (Kassarjian, 1977: 9). Kriter tanımlamalarını yapan araştırmacılar arasındaki tutarlılık, çalışmanın güvenirliğini göstermektedir. Güvenirliği test etmek için parametre tanımlamalarında araştırmacılar arasındaki tutarlılığı ölçen Kappa analizi yapılmalıdır (Kılıç, 2015: 142). Bu çalışmada tanımlamalar tek araştırmacı tarafından yapıldığından Kappa analizine gerek duyulmamıştır.

\section{Bulgular}

Çalışmanın bu kısmında araştırma kapsamındaki bankaların Instagram değerlendirme endeks puanlarının hesaplanması için popülerlik, etkileşim ve içerik parametrelerinin değer puanları hesaplanıp değerlendirilmiştir.

\section{Popülerlik değer puanı (PDP)}

Popülerlik değer puanı üç aşamada tespit edilmektedir. İlk aşamada türlerine göre sınıflandırılan bankaların takipçi sayıları, ikinci aşamada, bankaların Instagram hesaplarının popülerlik değerlerini 0 ila 100 arasında puanlayabilmek için "baz değer" tespit edilmesi gerekmektedir. En yüksek takipçi sayısına sahip banka Instagram hesabının takipçi sayısı, baz değeri teşkil etmektedir. Üçüncü aşamada, ilgili banka Instagram hesabının takipçi sayısı (t), / en yüksek takipçi sayısına sahip banka Instagram hesabının takipçi sayısına (baz/bd) bölünür ve 100 ile çarpılır.

$$
\begin{aligned}
& \text { Popülerlik Değer Puanı }=\frac{\text { İlgili Banka Instagram Hesabının Takipçi Sayısı (i) }}{\text { En Yüksek Takipçi Sayısına Sahip }} \times 100 \\
& \text { Banka Instagram Hesabının Takipçi Sayısı (Baz) }
\end{aligned}
$$

$\mathrm{Bu}$ işlem sonucunda ulaşılan değer, ilgili banka Instagram hesabının popülerlik değer puanını oluşturmaktadır (Miranda vd., 2013: 9-10). Tablo 2'de her bir bankanın "Popülerlik Değer Puanı"nın hesaplamasına yer verilmiştir. 
Tablo 2. Bankaların Popülerlik Değer Puanları

\begin{tabular}{|c|c|c|c|c|}
\hline \multirow{2}{*}{$\begin{array}{c}\text { Banka } \\
\text { Türleri }\end{array}$} & \multirow[t]{2}{*}{ Bankalar } & $\begin{array}{c}\text { Takipçi } \\
\text { Sayısı }\end{array}$ & Baz Değer & $(t / b d) x 100$ \\
\hline & & $t$ & $b d$ & $p d p$ \\
\hline \multirow{3}{*}{ KMB } & Vakıflar Bankası & 39.200 & 201.900 & 19,42 \\
\hline & Halk Bankası & 53.000 & 201.900 & 26.25 \\
\hline & Ziraat Bankası & 201.900 & 201.900 & 100 \\
\hline \multirow{6}{*}{ KB } & Ziraat Katılım Bankası & 33.900 & 34.100 & 99,41 \\
\hline & Vakıf Katılım Bankası & 10.000 & 34.100 & 29,33 \\
\hline & Türkiye Finans KB & 9.457 & 34.100 & 27,73 \\
\hline & Türkiye Emlak KB & 1.694 & 34.100 & 4,97 \\
\hline & Kuveyt Türk KB & 34.100 & 34.100 & 100 \\
\hline & Albaraka Türk KB & 18.900 & 34.100 & 55.43 \\
\hline \multirow{8}{*}{ ÖMB } & Yapı ve Kredi Bankası & 96.000 & 104.000 & 92,31 \\
\hline & Türkiye İş Bankası & 104.000 & 104.000 & 100 \\
\hline & Türk Ekonomi Bankası & 25.400 & 104.000 & 24,42 \\
\hline & Turkish Bank & 1.285 & 104.000 & 1,24 \\
\hline & Şekerbank & 6.095 & 104.000 & 5,86 \\
\hline & Fibabanka & 19.200 & 104.000 & 18,46 \\
\hline & Anadolubank & 1.948 & 104.000 & 1,87 \\
\hline & Akbank & 79.200 & 104.000 & 76,15 \\
\hline \multirow{13}{*}{ YMB } & Türkiye Garanti Bankası & 113.000 & 113.000 & 100 \\
\hline & Rabobank & 16.800 & 113.000 & 14,87 \\
\hline & QNB Finansbank & 43.800 & 113.000 & 38,76 \\
\hline & Odea Bank & 4.519 & 113.000 & 4,00 \\
\hline & ING Bank & 27.100 & 113.000 & 23,98 \\
\hline & ICBC Turkey Bank & 446 & 113.000 & 0,41 \\
\hline & HSBC Bank & 36.500 & 113.000 & 32,30 \\
\hline & Golden Global Bank & 39 & 113.000 & 0,03 \\
\hline & Deutsche Bank & 31.500 & 113.000 & 27,88 \\
\hline & Denizbank & 40.700 & 113.000 & 36,02 \\
\hline & Citibank & 63.300 & 113.000 & 56,02 \\
\hline & Burgan Bank & 785 & 113.000 & 0,69 \\
\hline & Alternatifbank & 4.749 & 113.000 & 4,20 \\
\hline
\end{tabular}

Tablo 2'ye göre Kamu Mevduat Bankaları (KMB) kategorisinde popülerlik değer puanı en yüksek olan banka Ziraat Bankası iken en düşük olan banka Vakıflar Bankasıdır. Bu kategorideki bankalar, devlet bankası olmaları sebebiyle tüketicilerin güvendiği finansal kurum olma özelliği taşımaktadırlar. Bu nedenle ülke içerisinde geniş bir kitleye hitap etmektedirler (Şakar, 2000: 19). Daha fazla Instagram takipçisine sahip olmak, bankanın veya markanın daha güvenilir görünmesini sağlamaktadır. Başka bir ifadeyle Instagram'da özgün ve güvenilir bir görünüme sahip olmak için daha fazla takipçiye ihtiyaç vardır (Ateş ve Karaduman, 2019: 176).

Katılım Bankaları kategorisinde Kuveyt Türk KB 34.100 takipçi sayısıyla en avantajlı banka konumundadır. Takipçi sayısının fazla olması, diğer katılım bankalarına göre Instagram hesabını aktif kullanması ile açıklanabilir. Türkiye Emlak Katılım Bankası ise 1.694 takipçi ile popülerlik değer puanı en düşük banka olarak tespit edilmiştir. Bu durum kuruluş itibariyle yeni bir banka olması ve sosyal medyayı aktif kullanmaması ile ilişkilendirilebilir.

ÖMB grubunu oluşturan bankalar, mevduat toplayıp, kredi kullandırma genel işlevi olan bankalardır. Toplanan mevduat ülkenin sanayi ve ticaretle uğraşan kesimin kredi ihtiyacı için kullandırılmaktadır (Kaya, 2012: 72). Sosyal medya kullanımları aktif olmasına rağmen, tüketici portföyü sınırlıdır. Daha çok cazip faiz oranları ile özel kişi/sektör ihtiyaçlarını karşılamaya yönelik faaliyetler göstermektedir. İş Bankası bu grupta, en yüksek takipçi sayısına sahip bankadır. Hem kuruluş itibariyle ülkenin ilk özel bankası olma özelliği taşıması, hem de diğer bankalara göre Instagram'da daha fazla aktif olması kullanıcı sayısının fazla olmasında etkili olduğu söylenebilir. Bu grupta yer alan diğer bankaların takipçi sayılarının İş Bankası'na oranla daha az olmasına belirli mesleki faaliyetlere hitap etmesi ve dolayısıyla sosyal medya hesaplarının aktif kullanılmaması gerekçe gösterilebilir.

YMB grubunu oluşturan bankalar, kamu hizmetlerinden bireysel bankacilık hizmetlerine, emeklilik yatırımlarından yurt dışı bankacılık hizmetlerine kadar pek çok alanda hizmet yelpazesine sahiptirler. Özellikle küçük ve orta ölçekli işletmeler ile bireysel tüketiciler hizmet verdiği en önemli portföy grubunu oluşturmaktadır (www.bankalar.org/). Bu bakımdan aktif sosyal medya kullanımının yanı sıra sürekli güncel, cazip ürün ve hizmetleri tüketicilere ulaştırması oldukça önem arz etmektedir. Rekabetin de yoğun olması bankaların sosyal medya gibi güncel pazarlama araçlarına yoğunlaşmasını 
zorunlu kılmaktadır. Türkiye Garanti Bankasının Instagram'ı pazarlama stratejilerine entegre ederek hedef kitlesine hızlı ve kolay bir şekilde ulaştığı söylenebilir. İlgili kategorideki diğer bankalara nazaran oldukça yüksek bir takipçi sayısının olması bu durumu desteklemektedir.

\section{Etkileşim değer puanı (EDP)}

Etkileşim değer puanı, aşağıda sıralanan etkileşim parametresi kriterlerine ilişkin değer puanlarının, her bir banka için hesaplanıp sonrasında bu dört değer puanının ortalamasının alınmasıyla ortaya çıan rakamı temsil etmektedir. Etkileşim parametresi kriterlerine ilişkin değer puanlarının hesaplanmasında aşağıdaki formülden yararlanılmıştır (Miranda vd., 2013: 9-10):

$$
\begin{aligned}
& \text { Etkileşim parametresi kriterinin değer puanı }=\frac{\text { İlgili Bankanın Etkileşim Değeri (i) }}{\text { En Yüksek Etkileşim Değerine Sahip }} \times 100 \\
& \text { Bankanın Etkileşim Değeri (Baz) }
\end{aligned}
$$

- Son 7 gün içinde banka tarafından paylaşılan duvar ileti sayısı

- Son 10 iletinin ortalama beğeni sayısı

- Son 10 iletiye yapılan ortalama yorum sayısı

- Son 24 saat içerisinde ve son 10 ileti arasından banka tarafından cevaplanan ortalama kullanıcı yorum paylaşılan ileti sayısı

\section{Son 7 gün içinde banka tarafından paylaşılan duvar ileti sayısı değer puanının (İP) hesaplanması}

Bu değer puanı, bankaların ürün ve hizmetlerinin kullanıcılarına tanıtımındaki etkinliğini ölçmektedir. Görünürlügü sürekli olarak artırmak ve geniş kitlelerin ürün ve hizmetlerden haberdar olmasını sağlamak için bankaların paylaştıkları iletiler önemli bir yer tutmaktadır. Tablo 3'te her bir bankanın "ip" hesaplamasına yer verilmiştir.

\begin{tabular}{|c|c|c|c|c|}
\hline $\begin{array}{l}\text { Banka } \\
\text { Türleri }\end{array}$ & Bankalar & $i$ & $b d$ & $\begin{array}{c}{[(i / b d) x(00)]} \\
{ }^{*} i p\end{array}$ \\
\hline \multirow{3}{*}{ КМB } & Vakıflar Bankası & 10 & 10 & 100 \\
\hline & Halk Bankası & 6 & 10 & 60 \\
\hline & Ziraat Bankası & 6 & 10 & 60 \\
\hline \multirow{6}{*}{ KB } & Ziraat Katılım Bankası & 5 & 9 & 55,55 \\
\hline & Vakıf Katılım Bankası & 9 & 9 & 100 \\
\hline & Türkiye Finans KB & 4 & 9 & 44,44 \\
\hline & Türkiye Emlak KB & 3 & 9 & 33,33 \\
\hline & Kuveyt Türk KB & 5 & 9 & 55,55 \\
\hline & Albaraka Türk KB & 6 & 9 & 66,66 \\
\hline \multirow{8}{*}{ ÖMB } & Yap1 ve Kredi Bankası & 4 & 9 & 44,44 \\
\hline & Türkiye İş Bankası & 4 & 9 & 44,44 \\
\hline & Türk Ekonomi Bankası & 9 & 9 & 100 \\
\hline & Turkish Bank & 7 & 9 & 77,77 \\
\hline & Şekerbank & 5 & 9 & 55,55 \\
\hline & Fibabanka & 5 & 9 & 55,55 \\
\hline & Anadolubank & 4 & 9 & 44,44 \\
\hline & Akbank & 3 & 9 & 33,33 \\
\hline \multirow{13}{*}{ YMB } & Türkiye Garanti Bankası & 11 & 11 & 100 \\
\hline & Rabobank & 5 & 11 & 45,45 \\
\hline & QNB Finansbank & 3 & 11 & 27,27 \\
\hline & Odea Bank & 3 & 11 & 27,27 \\
\hline & ING Bank & 2 & 11 & 18,18 \\
\hline & ICBC Turkey Bank & 3 & 11 & 27,27 \\
\hline & HSBC Bank & 0 & 11 & 0 \\
\hline & Golden Global Bank & 1 & 11 & 9,09 \\
\hline & Deutsche Bank & 6 & 11 & 54,54 \\
\hline & Denizbank & 10 & 11 & 90,90 \\
\hline & Citibank & 2 & 11 & 18,18 \\
\hline & Burgan Bank & 1 & 11 & 9,09 \\
\hline & Alternatifbank & 3 & 11 & 27,27 \\
\hline
\end{tabular}

Tablo 3. Son 7 Gün İçinde Banka Tarafından Paylaşılan Duvar İleti Sayısı Değer Puanı

$\boldsymbol{i}=$ Son 7 gün içinde banka tarafindan paylaşılan duvar ileti sayısı, $\boldsymbol{b} \boldsymbol{d}=$ Baz değer. 
Tablo 3'e bakıldığında Kamu Mevduat Bankaları kategorisinde 'ip' değeri en yüksek olan banka Vakıflar Bankası iken diğer iki bankanın 'ip' değerinin eşit olduğu görülmektedir. Benzer bir şekilde Katılım Bankaları kategorisinde Vakıf Katılım en avantajlı banka konumundadır. Türkiye Emlak Katılım Bankası 3 ileti sayısıyla KB içerisinde "ip" değeri en düşük banka olarak tespit edilmiştir. ÖMB kategorisinde TEB 'ip' değeri en yüksek banka iken Akbank 3 ileti sayısıyla "ip" değeri en düşük banka olarak belirlenmiştir. YMB kategorisinde Garanti Bankası günlük ileti paylaşımı bakımından kategorisindeki diğer bankalara göre daha aktiftir. HSBC Bank ise son 7 gün içerisinde hiçbir ileti paylaşmamıştır. KB kategorisinde Albaraka Türk KB (66.66); ÖMB grubunda Turkish Bank (77,77); YMB grubunda Denizbank $(90,90)$, Deutsche Bank $(54,54)$ ve Rabobank $(45,45)$ yüksek 'ip' değerine sahip dikkat çeken diğer bankalardır.

\section{Son 10 iletinin ortalama beğenilme sayısı değer puanının (OBP) hesaplanması}

$\mathrm{Bu}$ değer puanı, bankaların ürün ve hizmetlerinin kullanıcılar tarafından beğenilme oranını ölçmektedir. Tablo 4'te her bir bankanın 'obp' hesaplamasına yer verilmiştir.

Tablo 4. Her Bir Bankanın “Son 10 İletinin Ortalama Beğenilme Sayısı” Değer Puanı

\begin{tabular}{|c|c|c|c|c|c|}
\hline $\begin{array}{l}\text { Banka } \\
\text { Türleri }\end{array}$ & Bankalar & $b$ & $o b$ & $b d$ & ${ }^{*} o b p$ \\
\hline \multirow{3}{*}{ КМВ } & Vakıflar Bankası & 6197 & 619,7 & 681,7 & 90,90 \\
\hline & Halk Bankası & 6817 & 681,7 & 681,7 & 100 \\
\hline & Ziraat Bankası & 4620 & 462 & 681,7 & 67,77 \\
\hline \multirow{6}{*}{ KB } & Ziraat Katılım Bankası & 5686 & 568,6 & 568,6 & 100 \\
\hline & Vakıf Katılım Bankası & 2122 & 212,2 & 568,6 & 37,31 \\
\hline & Türkiye Finans KB & 4585 & 458,5 & 568,6 & 80,63 \\
\hline & Türkiye Emlak KB & 953 & 95,3 & 568,6 & 16,76 \\
\hline & Kuveyt Türk KB & 2535 & 253,5 & 568,6 & 44,58 \\
\hline & Albaraka Türk KB & 2541 & 254,1 & 568,6 & 44,68 \\
\hline \multirow{8}{*}{ ÖMB } & Yap1 ve Kredi Bankası & 17776 & 1777,6 & 2686,3 & 66,17 \\
\hline & Türkiye İş Bankası & 26863 & 2686,3 & 2686,3 & 100 \\
\hline & Türk Ekonomi Bankası & 2569 & 256,9 & 2686,3 & 9,56 \\
\hline & Turkish Bank & 371 & 37,1 & 2686,3 & 1,38 \\
\hline & Şekerbank & 2185 & 218,5 & 2686,3 & 8,13 \\
\hline & Fibabanka & 1418 & 141,8 & 2686,3 & 5,27 \\
\hline & Anadolubank & 9672 & 967,2 & 2686,3 & 36 \\
\hline & Akbank & 4617 & 461,7 & 2686,3 & 17,18 \\
\hline \multirow{13}{*}{ YMB } & Türkiye Garanti Bankası & 11327 & 1132,7 & 2059,4 & 55 \\
\hline & Rabobank & 1565 & 156,5 & 2059,4 & 7,59 \\
\hline & QNB Finansbank & 3727 & 372,7 & 2059,4 & 18,09 \\
\hline & Odea Bank & 4229 & 422,9 & 2059,4 & 20,53 \\
\hline & ING Bank & 6200 & 620 & 2059,4 & 30,10 \\
\hline & ICBC Turkey Bank & 589 & 58,9 & 2059,4 & 2,86 \\
\hline & HSBC Bank & 4356 & 435,6 & 2059,4 & 21,15 \\
\hline & Golden Global Bank & 81 & 8,1 & 2059,4 & 0,39 \\
\hline & Deutsche Bank & 3141 & 314,1 & 2059,4 & 15,25 \\
\hline & Denizbank & 20594 & 2059,4 & 2059,4 & 100 \\
\hline & Citibank & 1876 & 187,6 & 2059,4 & 9,10 \\
\hline & Burgan Bank & 652 & 65,2 & 2059,4 & 3,16 \\
\hline & Alternatifbank & 707 & 70,7 & 2059,4 & 3,43 \\
\hline
\end{tabular}

Kamu Mevduat Bankaları kategorisinde Halk Bankası 681,7 ortalama beğeni sayısıyla "obp" değeri en yüksek olan banka iken en düşük banka ise Ziraat Bankası'dır. Katılım Bankaları kategorisinde Ziraat Katılım 568,6 ortalama beğeni sayısıyla en avantajlı banka konumundadır. Türkiye Emlak KB 95,3 ortalama beğeni sayısıyla KB içerisinde "obp" değeri en düşük banka olarak tespit edilmiştir. ÖMB kategorisinde Türkiye İş Bankası 2.686,3 ortalama beğeni sayısıyla "obp" değeri en yüksek banka olarak belirlenirken Turkish Bank en düşük banka olarak tespit edilmiştir. Denizbank 2.059,4 ortalama beğeni sayısıyla kategorisindeki "obp" değeri en yüksek bankadır. 


\section{Son 10 iletiye yapılan ortalama yorum sayısı değer puanının (OYP) hesaplanması}

Bu değeri puanı, bankaların ürün ve hizmetlere kullanıcılar tarafından olumlu ve/veya olumsuz yapılan geri dönüşleri ölçmektedir. Bu değerin sonuçları, Instagram ileti paylaşımlarıyla doğru orantılıdır. Tablo 5'te her bir bankanın "oyp" hesaplamasına yer verilmiştir.

Tablo 5. Her Bir Bankanın “Son 10 İletiye Yapılan Ortalama Yorum Sayısı” Değer Puanı

\begin{tabular}{|c|c|c|c|c|c|}
\hline $\begin{array}{l}\text { Banka } \\
\text { Türleri }\end{array}$ & Bankalar & $y$ & oy & $b d$ & $\begin{array}{c}(y / b d) x 100 \\
\text { oyp }\end{array}$ \\
\hline \multirow{3}{*}{ KMB } & Vakıflar Bankası & 18 & 1,8 & 36,8 & 4,89 \\
\hline & Halk Bankası & 368 & 36,8 & 36,8 & 100 \\
\hline & Ziraat Bankası & 45 & 4,5 & 36,8 & 12,22 \\
\hline \multirow{6}{*}{ KB } & Ziraat Katılım Bankası & 420 & 42 & 42 & 100 \\
\hline & Vakıf Katılım Bankası & 18 & 1,8 & 42 & 4,28 \\
\hline & Türkiye Finans KB & 17 & 1,7 & 42 & 4,04 \\
\hline & Türkiye Emlak KB & 6 & 0,6 & 42 & 1,42 \\
\hline & Kuveyt Türk KB & 33 & 3,3 & 42 & 7,85 \\
\hline & Albaraka Türk KB & 40 & 4 & 42 & 9,52 \\
\hline \multirow{8}{*}{ ÖMB } & Yapı ve Kredi Bankası & 438 & 43,8 & $\overline{63,4}$ & 69,08 \\
\hline & Türkiye İş Bankası & 634 & 63,4 & 63,4 & 100 \\
\hline & Türk Ekonomi Bankası & 41 & 4,1 & 63,4 & 6,46 \\
\hline & Turkish Bank & 3 & 0,3 & 63,4 & 0,47 \\
\hline & Şekerbank & 16 & 1,6 & 63,4 & 2,52 \\
\hline & Fibabanka & 75 & 7,5 & 63,4 & 11,82 \\
\hline & Anadolubank & 16 & 1,6 & 63,4 & 2,52 \\
\hline & Akbank & 249 & 24,9 & 63,4 & 39,27 \\
\hline \multirow{13}{*}{ YMB } & Türkiye Garanti Bankası & 329 & 32,9 & 32,9 & 100 \\
\hline & Rabobank & 22 & 2,2 & 32,9 & 6,68 \\
\hline & QNB Finansbank & 98 & 9,8 & 32,9 & 29,78 \\
\hline & Odea Bank & 17 & 1,7 & 32,9 & 5,16 \\
\hline & ING Bank & 206 & 20,6 & 32,9 & 62,61 \\
\hline & ICBC Turkey Bank & 4 & 0,4 & 32,9 & 1,21 \\
\hline & HSBC Bank & 193 & 19,3 & 32,9 & 58,66 \\
\hline & Golden Global Bank & 2 & 0,2 & 32,9 & 0,60 \\
\hline & Deutsche Bank & 50 & 5 & 32,9 & 15,19 \\
\hline & Denizbank & 285 & 28,5 & 32,9 & 86,62 \\
\hline & Citibank & 324 & 32,4 & 32,9 & 98,48 \\
\hline & Burgan Bank & 4 & 0,4 & 32,9 & 1,21 \\
\hline & Alternatifbank & 4 & 0,4 & 32,9 & 1,21 \\
\hline
\end{tabular}

$\mathbf{y = ~ S o n ~} 10$ İletiye Yapılan Toplam Yorum Sayısı, oy=Ortalama Yorum Sayısı, bd=Baz Değer.

Tablo 5'e göre KMB kategorisinde "oyp" değeri en yüksek olan banka Halk Bankası iken en düşük banka Vakıflar Bankası'dır (4.89). KB kategorisinde Ziraat Katılım 42 ortalama yorum sayısıyla en avantajlı banka konumunda iken Türkiye Emlak KB 0,6 ortalama yorum sayısıyla kategorisindeki "oyp" değeri en düşük banka olarak tespit edilmiştir. ÖMB kategorisinde İş Bankası 63,4; YMB kategorisinde Garanti Bankası kategorilerindeki "oyp" değeri en yüksek bankalardır. Ayıca ÖMB kategorisinde Yapı ve Kredi Bankası $(69,08)$, Akbank $(39,27)$ ve YMB kategorisinde Citibank, Denizbank, ING Bank ve HSBC Bank sırasıyla 98,48, 86,62, 62,61 ve 58,66 “oyp" değer puanı ile dikkat çeken diğer bankalar olarak söylenebilir.

Son 24 saat içerisinde ve son 10 ileti arasından banka tarafından cevaplanan ortalama kullanıcı yorum sayısı değer puanının (OCP) hesaplanması

$\mathrm{Bu}$ değer puanı, bankaların ürün ve hizmetlerine kullanıcılar tarafından olumlu ve/veya olumsuz yapılan bildirimlere kurumca geri dönüşlerin durumunu ölçmektedir. Tablo 6'da her bir bankanın "ocp" hesaplamasına yer verilmiştir. 
Tablo 6. Her Bir Bankanın "Son 24 Saat İçerisinde ve Son 10 İleti Arasından Banka Tarafından Cevaplanan Ortalama Kullanıcı Yorum Sayısı” Değer Puanı

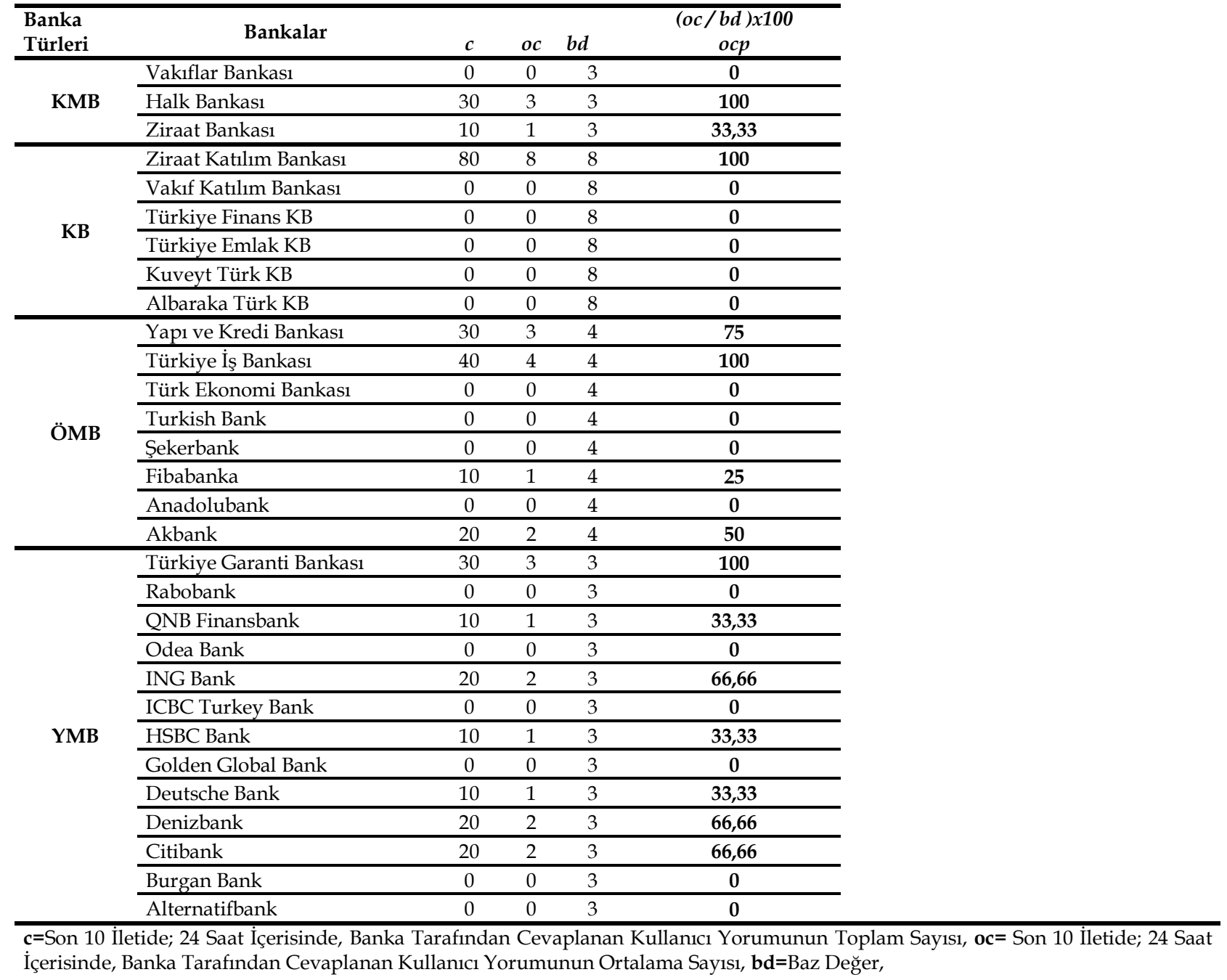

Tablo 6'da görüldüğü üzere KMB kategorisinde Halk Bankası; KB kategorisinde Ziraat Katılım, ÖMB kategorisinde İş Bankası; YMB kategorisinde Garanti Bankası “ocp” değeri en yüksek olan bankalardır. Katılım Bankaları kategorisinde Ziraat Katılım dışındaki diğer bankalar iletilerine son 24 saat içerisinde yapılan yorumların hiçbirine geri dönüş yapmamıştır. ÖMB kategorisinde Yapı ve Kredi Bankası, Akbank ve Fibabank 'ın sırasıyla "ocp" değerleri 3, 2 ve 1'dir. Diğer bankaların "ocp" değerleri 0 olarak tespit edilmiştir.

Tablo 7'de her bir bankanın yukarıda hesaplanan "ip", "obp", "oyp" ve "ocp" değerlerinin aritmetik ortalaması alınarak ortaya çıkarılan "Nihai Etkileşim Değer Puanı (edp)" sonuçlarına yer verilmiştir.

Nihai etkileşim değer puanı, bankaların ürün ve hizmetlerinin tanıtımı için paylaştıkları ileti sayısı, kullanııların paylaşımları beğenme sayısı, paylaşımlara yapılan yorum sayısı ve bankanın yapılan yorumlara geri bildirimde bulunma sayısı kriterleri dikkate alınarak hesaplanmıştır. Tablo $7^{\prime}$ de Instagram etkileşimi konusunda KMB grubunda Halk Bankası, KB grubunda Ziraat Katılım Bankası, ÖMB grubunda Türkiye İş Bankası ve YMB grubunda Türkiye Garanti Bankası'nın en yüksek değer puanına sahip olduğu görülmektedir. Instagram'ın pazarlama aracı olarak etkin bir şekilde kullanılmadan önce anlaşılması gereken kendi kültürü vardır. Kaliteli fotoğraf ve videografi bir zorunluluktur, ancak popüler bir hesapta bundan daha fazlası olması gerekmektedir. Instagram içeriği takipçi beklentilerini karşılamalıdır. Bankanın etkileşim oranının yüksek olması, tüketiciler ile banka arasında bir bağ oluştuğunun bir göstergesidir. Paylaşılan içeriklere önem verdiklerini ve devamlı olarak müşterilerini takip ettiklerini göstermektedir. Bu da bankanın bilinirliğini ve güvenilirliğini olumlu yönde etkilemektedir. 
Tablo 7. Her Bir Bankanın Nihai Etkileşim Değer Puanı

\begin{tabular}{|c|c|c|c|c|c|c|}
\hline Banka Türleri & Bankalar & $\begin{array}{l}i p \\
(a)\end{array}$ & $\begin{array}{c}o b p \\
(b)\end{array}$ & $\begin{array}{c}o y p \\
(c)\end{array}$ & $\begin{array}{l}o c p \\
(d)\end{array}$ & $\begin{array}{c}(a+b+c+d) / 4 \\
e d p\end{array}$ \\
\hline \multirow{3}{*}{ KMB } & Vakıflar Bankası & 100 & 90,90 & 4,89 & 0 & 48,94 \\
\hline & Halk Bankası & 60 & 100 & 100 & 100 & 90 \\
\hline & Ziraat Bankası & 60 & 67,77 & 12,22 & 33,33 & 43,33 \\
\hline \multirow{6}{*}{ KB } & Ziraat Katılım Bankası & 55,55 & 100 & 100 & 100 & 88,88 \\
\hline & Vakıf Katılım Bankası & 100 & 37,31 & 4,28 & 0 & 35,40 \\
\hline & Türkiye Finans KB & 44,44 & 80,63 & 4,04 & 0 & 32,28 \\
\hline & Türkiye Emlak KB & 33,33 & 16,76 & 1,42 & 0 & 12,88 \\
\hline & Kuveyt Türk KB & 55,55 & 44,58 & 7,85 & 0 & 26,99 \\
\hline & Albaraka Türk KB & 66,66 & 44,68 & 9,52 & 0 & 30,21 \\
\hline \multirow{8}{*}{ ÖMB } & Yapı ve Kredi Bankası & 44,44 & 66,17 & 69,08 & 75 & 63,67 \\
\hline & Türkiye İş Bankası & 44,44 & 100 & 100 & 100 & 86,11 \\
\hline & Türk Ekonomi Bankası & 100 & 9,56 & 6,46 & 0 & 29,00 \\
\hline & Turkish Bank & 77,77 & 1,38 & 0,47 & 0 & 19,90 \\
\hline & Şekerbank & 55,55 & 8,13 & 2,52 & 0 & 16,55 \\
\hline & Fibabanka & 55,55 & 5,27 & 11,82 & 25 & 24,41 \\
\hline & Anadolubank & 44,44 & 36 & 2,52 & 0 & 20,74 \\
\hline & Akbank & 33,33 & 17,18 & 39,27 & 50 & 34,94 \\
\hline \multirow{13}{*}{ YMB } & Türkiye Garanti Bankası & 100 & 55 & 100 & 100 & 88,75 \\
\hline & Rabobank & 45,45 & 7,59 & 6,68 & 0 & 14,93 \\
\hline & QNB Finansbank & 27,27 & 18,09 & 29,78 & 33,33 & 27,12 \\
\hline & Odea Bank & 27,27 & 20,53 & 5,16 & 0 & 13,24 \\
\hline & ING Bank & 18,18 & 30,10 & 62,61 & 66,66 & 44,39 \\
\hline & ICBC Turkey Bank & 27,27 & 2,86 & 1,21 & 0 & 7,83 \\
\hline & HSBC Bank & 0 & 21,15 & 58,66 & 33,33 & 28,28 \\
\hline & Golden Global Bank & 9,09 & 0,39 & 0,60 & 0 & 2,52 \\
\hline & Deutsche Bank & 54,54 & 15,25 & 15,19 & 33,33 & 29,58 \\
\hline & Denizbank & 90,90 & 100 & 86,62 & 66,66 & 86,05 \\
\hline & Citibank & 18,18 & 9,10 & 98,48 & 66,66 & 48,10 \\
\hline & Burgan Bank & 9,09 & 3,16 & 1,21 & 0 & 3,36 \\
\hline & Alternatifbank & 27,27 & 3,43 & 1,21 & 0 & 7,98 \\
\hline
\end{tabular}

ip= Son 7 Gün İçinde Kuruluş Tarafından Yapılan Duvar İleti Sayısı Değeri Puanı, obp=Son 10 İletinin Ortalama Beğeni Sayısı Değer Puanı, oyp=Son 10 İletiye Yapılan Ortalama Yorum Sayısı Değer Puanı, ocp=Cevaplanan Kullanıcı Yorumunun Ortalama Sayısı Değer Puanı.

\section{İçerik değer puanı (IDP)}

Bankaların içerik parametresi kriterlerinin değer puanları aşağıdaki formül yardımıyla hesaplanmaktadır. Bu işlem aşağıda sıralanan her bir içerik parametresi kriteri için ayrı ayrı yapılır (Miranda vd., 2013: 9-10):

$$
\begin{gathered}
\text { İçerik parametresi kriterinin değer puanı= } \frac{\text { İlgili Bankanın İçerik Değeri (i) }}{\text { En Yüksek İçerik Değerine Sahip }} \times 100 \\
\text { Bankanın İçerik Değeri (Baz) }
\end{gathered}
$$

- Videolar

- Ürün bilgileri

- Fotoğraflar

- Kurumsal kimlik (Logo)

- Pazarlama mesajları
- Etkinlikler

- Sosyal duyarlılık etkinlikleri

- Kuponlar ve özel teklifler

- Oyunlaştırma uygulamaları / Yarışmalar

- Talep ve öneriler

Yukarıda sıralanan 10 farklı içerik parametresi kriterinin değer puanlarının aritmetik ortalaması, her bankanın içerik değer puanını (idp) oluşturmaktadır. Bu kısımda türlerine göre gruplandırılan bankaların ayrı ayrı içerik değer puanlarına yer verilecektir. Tablo 8' de KMB kategorisindeki bankaların içerik değer puanları gösterilmektedir. 
Tablo 8. KMB İçerik Değer Puanı

\begin{tabular}{|c|c|c|c|c|c|c|c|}
\hline Kriterler & $b d$ & $\overline{Z B}$ & HB & $V B$ & $(\mathrm{ZB} / \mathrm{bd}) \times 100$ & $(\mathrm{HB} / \mathrm{bd}) \times 100$ & $(V B / b d) x 100$ \\
\hline Videolar & 50 & 18 & 38 & 50 & 36 & 76 & 100 \\
\hline Ürün bilgileri & 120 & 95 & 90 & 120 & 79,16 & 75 & 100 \\
\hline Fotoğraflar & 115 & 114 & 115 & 100 & 99,13 & 100 & 86,95 \\
\hline Kurumsal kimlik (Logo) & 112 & 110 & 112 & 100 & 98,21 & 100 & 89,28 \\
\hline Pazarlama mesajları & 95 & 90 & 88 & 95 & 94,73 & 92,63 & 100 \\
\hline Talep ve öneriler & 60 & 44 & 52 & 60 & 73,33 & 86,66 & 100 \\
\hline Etkinlikler & 25 & 19 & 17 & 25 & 76 & 68 & 100 \\
\hline Sosyal duyarlılık etkinlikleri & 23 & 22 & 22 & 23 & 95,65 & 95,65 & 100 \\
\hline Kuponlar ve özel teklifler & 15 & 10 & 12 & 15 & 66,66 & 80 & 100 \\
\hline \multirow[t]{3}{*}{ Oyunlaştırma uyg. / Yarışmalar } & 6 & 4 & 3 & 6 & 66,66 & 50 & 100 \\
\hline & TOPLAM & 526 & 549 & 594 & $785,56^{*}$ & $823,95^{*}$ & $976,24^{*}$ \\
\hline & \multicolumn{4}{|c|}{ İçerik Değer Puanı ("/10) } & 78,55 & 82,39 & 97,62 \\
\hline
\end{tabular}

$\mathbf{Z B}=$ Ziraat Bankası, $\mathbf{H B}=$ Halk Bankası $\mathbf{V B}=$ Vakıfbank, $\boldsymbol{b d}=$ Baz Değer

Tablo 8'de yer alan bilgilere göre; “İçerik Değer Puanı” en yüksek banka Vakıflar Bankası $(97,62)$ iken en düşük olan banka ise Ziraat Bankası' dır $(78,55)$. Öte yandan Vakıflar Bankası, kategorisindeki diğer bankalara göre çok sayıda içerik parametresinde güçlü konumda olmasına rağmen kurumsal kimlik (logo) ve fotoğraf paylaşımı konusunda rakiplerinin gerisinde yer almaktadır. $\mathrm{Bu}$ parametre kriterlerindeki dezavantajını sunmuş olduğu ürün ve hizmetlerle ilgili bilgi paylaşımı yaparak dengelediği görülmektedir. Kategorideki bankaların tümü toplumun hassasiyet gösterdiği konularda benzer düzeyde paylaşımda bulunmuştur. Tablo 9' da KB gurubunun içerik değer puanları verilmiştir.

Tablo 9. KB İçerik Değer Puanı

\begin{tabular}{|c|c|c|c|c|c|c|c|}
\hline Kriterler & $\overline{b d}$ & $A T K B^{* *}$ & $K_{T K B^{* *}}$ & $T^{T E K B^{* *}}$ & TFKB $^{* *}$ & $V K B^{* *}$ & $Z K B^{* *}$ \\
\hline Videolar & 105 & 85,71 & 100 & 14,28 & 42,85 & 64,76 & 11,42 \\
\hline Ürün bilgileri & 110 & 80,90 & 100 & 7,27 & 63,63 & 72,72 & 54,54 \\
\hline Fotoğraflar & 122 & 93,44 & 100 & 7,37 & 73,77 & 86,88 & 95,90 \\
\hline Kurumsal kimlik (Logo) & 114 & 89,47 & 100 & 12,28 & 74,56 & 85,96 & 36,84 \\
\hline Pazarlama mesajları & 100 & 82 & 100 & 6 & 75 & 78 & 46 \\
\hline Talep ve öneriler & 46 & 84,78 & 100 & 2,17 & 54,34 & 63,04 & 65,21 \\
\hline Etkinlikler & 40 & 70 & 100 & 2,50 & 45 & 50 & 55 \\
\hline Sosyal duyarlılık etkinlikleri & 65 & 89,23 & 100 & 1,53 & 61,53 & 86,15 & 92,30 \\
\hline Kuponlar ve özel teklifler & 30 & 83,33 & 100 & 0 & 63,33 & 66,66 & 73,33 \\
\hline \multirow[t]{2}{*}{ Oyunlaştırma uyg./ Yarışmalar } & 1 & 100 & 100 & 100 & 100 & 100 & 100 \\
\hline & Toplam & $858,88^{*}$ & $1000^{*}$ & $153,4^{*}$ & $654,04^{*}$ & $754,2^{*}$ & $630,57^{*}$ \\
\hline \multicolumn{2}{|c|}{ İcerik Değer Puanı $(* / 10)$} & 85,88 & $\overline{100,0}$ & 15,34 & 65,40 & 75,42 & 63,05 \\
\hline
\end{tabular}

Not: $A T K B=$ Albaraka Türk $K B, K T K B=K u v e y t$ Türk $K B, T E K B=$ Türkiye Emlak $K B, T F K B=$ Türkiye Finans $K B, V K B=V a k l f K B$,

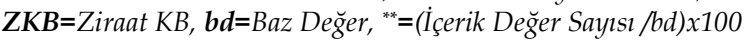

Tablo 9'a göre Katılım Bankaları kategorisinde içerik değer puanı en yüksek olan banka Kuveyt Türk KB' dır. İçerik etkinliği açısından bakıldığında kategorisindeki bankaların gerisinde olan Türkiye Emlak Katılım Bankası 15,34 puan ile içerik değer puanı en düşük olan bankadır. Bu bankanın kategorisindeki rakiplerine göre pazarlama içerikli az sayıda paylaşım yapması Intagram'ı hedef kitleye ulaşmada bir araç olarak görmediğinin bir göstergesi olabilir. ÖMB kategorisindeki bankaların içerik değer puanları Tablo 10 ' da gösterilmiştir.

Tablo 10'a bakıldığında ÖMB kategorisinde Türkiye İş Bankası'nın Instagram içeriği açısından rakiplerine fark attığı görülmektedir. İş Bankası'nın müşterilerine özel teklifler sunma ve sosyal duyarlılık etkinliklerine ilişkin paylaşımlarda bulunma konularına ağırlık verdiği tespit edilmiştir. İş Bankası'nı, içerik değer puanı sıralamasında TEB $(69,97)$, Akbank $(65,59)$ ve Fibabanka $(63,71)$ takip etmektedir. Öte yandan Şekerbank ve Anadolubank'ın sıralamanın gerisinde kaldığını söylemek yanlış olmayacaktır. 
Tablo 10. ÖMB İçerik Değer Puanı

\begin{tabular}{|c|c|c|c|c|c|c|c|c|c|}
\hline Kriterler & bd & $\mathbf{A K B}^{* *}$ & $\mathrm{ANB}^{* *}$ & $\mathbf{F B}^{* *}$ & ŞB $^{* *}$ & TUB $^{* *}$ & TEB $^{* *}$ & TİB $^{* *}$ & $\mathbf{Y K B}^{* *}$ \\
\hline Videolar & 100 & 70 & 62 & 100 & 20 & 44 & 50 & 72 & 48 \\
\hline Ürün bilgileri & 120 & 62,5 & 50 & 79,16 & 41,66 & 83,33 & 100 & 54,16 & 43,33 \\
\hline Fotoğraflar & 100 & 30 & 31 & 20 & 64 & 88 & 100 & 72 & 45 \\
\hline Kurumsal kimlik (Logo) & 100 & 43 & 35 & 86 & 50 & 95 & 100 & 90 & 40 \\
\hline Pazarlama mesajları & 100 & 44 & 32 & 80 & 48 & 90 & 100 & 60 & 30 \\
\hline Talep ve öneriler & 72 & 100 & 27,77 & 50 & 27,77 & 41,66 & 63,88 & 90,27 & 30,55 \\
\hline Etkinlikler & 35 & 100 & 51,42 & 80 & 40 & 22,85 & 34,28 & 91,42 & 54,28 \\
\hline Sosyal duyarlılık etkinlikleri & 40 & 55 & 42,5 & 57,5 & 75 & 20 & 50 & 100 & 52,5 \\
\hline Kuponlar ve özel teklifler & 35 & 51,42 & 34,28 & 40 & 22,85 & 14,28 & 57,14 & 100 & 54,28 \\
\hline \multirow[t]{2}{*}{ Oyunlaştırma uyg. / Yarışmalar } & 27 & 100 & 29,62 & 44,44 & 14,81 & 3,70 & 44,44 & 96,29 & 37,03 \\
\hline & Toplam & $655,92^{*}$ & $395,62^{*}$ & $637,1^{*}$ & $404,1^{*}$ & $502,84^{*}$ & $699,76^{*}$ & $826,16^{*}$ & $434,99^{*}$ \\
\hline \multicolumn{2}{|c|}{ İçerik Değer Puanı $\left({ }^{*} / 10\right)$} & 65,59 & 39,56 & 63,71 & 40,41 & 50,28 & 69,97 & 82,61 & 43,49 \\
\hline
\end{tabular}

AKB=Akbank, ANB=Anadolubank, FB=Fibabanka, ŞB=Şekerbank, TUB=Turkish Bank, TEB=Türk Ekonomi Bankası, TİB=Türkiye İş Bankası, YKB=Yapı ve Kredi Bankası, bd=Baz Değer, ${ }^{* *}=(I ̇ c ̧ e r i k$ Değer Sayısı /bd) $x 100$

Tablo 11. YMB İçerik Değer Puanı

\begin{tabular}{|c|c|c|c|c|c|c|c|}
\hline Kriterler & bd & $\mathrm{ALB}^{* *}$ & $\mathbf{B B}^{* *}$ & $\mathrm{CB}^{* *}$ & $\mathbf{D B}^{* *}$ & $\mathrm{DEB}^{* *}$ & $\mathrm{GGB}^{* *}$ \\
\hline Videolar & 75 & 41,33 & 13,33 & 16 & 80 & 40 & 2,66 \\
\hline Ürün bilgileri & 90 & 100 & 18,88 & 11,11 & 44,44 & 13,33 & $\overline{1,11}$ \\
\hline Fotoğraflar & 80 & 88,75 & 21,25 & 37,5 & 88,75 & 75 & 12,5 \\
\hline Kurumsal kimlik (Logo) & 85 & 100 & 32,94 & 18,82 & 47,05 & 14,11 & 1,17 \\
\hline Pazarlama mesajları & 70 & 100 & 28,57 & 11,42 & 45,71 & 7,14 & 1,42 \\
\hline Talep ve öneriler & 40 & 37,5 & 17,5 & 7,5 & 100 & 12,5 & 0 \\
\hline Etkinlikler & 85 & 11,76 & 2,35 & 38,82 & 70,58 & 100 & 12,94 \\
\hline Sosyal duyarlılık etkinlikleri & 80 & 15 & 12,5 & 37,5 & 43,75 & 100 & 13,75 \\
\hline Kuponlar ve özel teklifler & 8 & 75 & 25 & 25 & 50 & 25 & 12,5 \\
\hline \multirow[t]{3}{*}{ Oyunlaştırma uyg./Yarışmalar } & 12 & 25 & 16,66 & 8,33 & 100 & 16,66 & 8,33 \\
\hline & Toplam* & 594,34 & 189,00 & 212,02 & 670,30 & 403,76 & 66,40 \\
\hline & $\operatorname{lan} 1\left({ }^{*} / 10\right)$ & 59,43 & 18,90 & 21,20 & 67,03 & 40,37 & 6,64 \\
\hline Kriterler & HSBC $^{* *}$ & ICBC $^{* *}$ & $\mathrm{ING}^{* *}$ & $\mathbf{O B}^{* *}$ & $\mathrm{QNB}^{* *}$ & $\mathbf{R B}^{* *}$ & TGB $^{* *}$ \\
\hline Videolar & 21,33 & 5,33 & 66,66 & $\overline{46,66}$ & 65,33 & 53,33 & 100 \\
\hline Ürün bilgileri & 1,11 & 8,88 & 24,44 & 47,77 & 55,55 & 55,55 & 75,55 \\
\hline Fotoğraflar & 21,25 & 17,5 & 31,25 & 48,75 & 65 & 77,5 & 100 \\
\hline Kurumsal kimlik (Logo) & 3,52 & 11,76 & 35,29 & 52,94 & 64,70 & 81,17 & 88,23 \\
\hline Pazarlama mesajları & 1,42 & 1,42 & 34,28 & 50 & 97,14 & 94,28 & 98,57 \\
\hline Talep ve öneriler & 0 & 5 & 25 & 30 & 35 & 35 & 47,5 \\
\hline Etkinlikler & 37,64 & 11,76 & 21,17 & 21,17 & 34,11 & 25,88 & 32,94 \\
\hline Sosyal duyarlılık etkinlikleri & 40 & 13,75 & 25 & 22,5 & 27,5 & 25 & 40 \\
\hline Kuponlar ve özel teklifler & 12,5 & 12,5 & 62,5 & 100 & 50 & 37,5 & 75 \\
\hline \multirow{3}{*}{$\begin{array}{r}\text { Oyunlaştırma uyg./Yarışmalar } \\
\text { Toplam* } \\
\text { İçerik Değer Puanı (*/10) }\end{array}$} & 8,33 & 8,33 & 75 & 83,33 & 100 & 91,66 & 75 \\
\hline & 147,13 & 96,26 & 400,61 & 503,14 & 594,35 & 576,90 & 732,80 \\
\hline & 14,71 & 9,62 & 40,06 & 50,31 & 59,43 & 57,69 & 73,28 \\
\hline
\end{tabular}

$A L B=$ Alternatifbank, $B B=$ Burgan Bank, $C B=$ Citibank, $\mathbf{D B}=$ Denizbank, $\mathbf{D E B}=$ Deutsche Bank, $G G B=$ Golden Global Bank, $H S B C=H S B C$ Bank, ICBC=ICBC Turkey Bank, ING=ING Bank, $\boldsymbol{O B}=$ Odea Bank, $Q N B=Q N B$ Finansbank, $R B=$ Rabobank, TGB=Türkiye Garanti

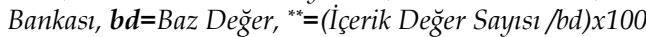

Tablo 11 incelendiğinde YMB kategorisinde içerik değer puanı en yüksek banka Türkiye Garanti Bankası'dır (73,28). İkinci sırada 67,03 içerik değer puanı ile Denizbank yer almaktadır. Öte yandan ICBC Turkey Bank $(9,62)$ ile Golden Global Bank $(6,64)$ kategorisindeki içerik değer puanı en düşük bankalardır. Bu bankaların rakiplerine kıyasla talep ve öneri içerikli paylaşımlarda bulunmaması ise ilginçtir.

\section{Instagram değerlendirme endeksi (IDE)}

Araştırma kapsamındaki bankaların popülerlik, etkileşim ve içerik parametre değer puanları belirlendikten sonra nihai Instagram Değerlendirme Endeks (IDE) puanı hesaplanmıştır. Her bankanın IDE puanı, ilgili bankanın popülerlik değer puanının \%25'i, etkileşim değer puanının \% 40 '1 ve içerik değer puanının \%35'inin toplamından oluşmaktadır (Miranda vd., 2013: 10). 
Tablo 12' de KMB, KB, ÖMB ve YMB kategorilerindeki bankaların Instagram değerlendirme endeks puanları sunulmuştur.

Tablo 12. Bankaların Instagram Değerlendirme Endeks (IDE) Puanları

\begin{tabular}{|c|c|c|c|c|c|}
\hline Kategoriler & Bankalar & $\begin{array}{l}p d p \\
\% 25\end{array}$ & $\begin{array}{l}e d p \\
\% 40\end{array}$ & $\begin{array}{c}i d p \\
\% 35\end{array}$ & $I D E$ \\
\hline \multirow{3}{*}{ KMB } & Vakıflar Bankası & 19,42 & 48,94 & 97,62 & 58,60 \\
\hline & Halk Bankası & 26,25 & 90 & 82,39 & 71,40 \\
\hline & Ziraat Bankası & 100 & 43,33 & 78,55 & 69,82 \\
\hline \multirow{6}{*}{ KB } & Ziraat Katılım Bankası & 99,41 & 88,88 & 63,05 & 82,47 \\
\hline & Vakıf Katılım Bankası & 29,33 & 35,40 & 75,42 & 47,89 \\
\hline & Türkiye Finans KB & 27,73 & 32,28 & 65,40 & 42,73 \\
\hline & Türkiye Emlak KB & 4,97 & 12,88 & 15,34 & 11,75 \\
\hline & Kuveyt Türk KB & 100 & 26,99 & 100 & 70,79 \\
\hline & Albaraka Türk KB & 55,43 & 30,21 & 85,88 & 56,00 \\
\hline \multirow{8}{*}{ ÖMB } & Yapı ve Kredi Bankası & 92,31 & 63,67 & 43,49 & 63,77 \\
\hline & Türkiye İş Bankası & 100 & 86,11 & 82,61 & 88,36 \\
\hline & Türk Ekonomi Bankası & 24,42 & 29,00 & 69,97 & 42,19 \\
\hline & Turkish Bank & 1,24 & 19,90 & 50,28 & 25,87 \\
\hline & Şekerbank & 5,86 & 16,55 & 40,41 & 22,23 \\
\hline & Fibabanka & 18,46 & 24,41 & 63,71 & 36,68 \\
\hline & Anadolubank & 1,87 & 20,74 & 39,56 & 22,61 \\
\hline & Akbank & 76,15 & 34,94 & 65,59 & 55,97 \\
\hline \multirow{13}{*}{ YMB } & Türkiye Garanti Bankası & 100 & 88,75 & 73,28 & 86,14 \\
\hline & Rabobank & 14,87 & 14,93 & 57,69 & 29,88 \\
\hline & QNB Finansbank & 38,76 & 27,12 & 59,43 & 41,34 \\
\hline & Odea Bank & 4 & 13,24 & 50,31 & 23,90 \\
\hline & ING Bank & 23,98 & 44,39 & 40,06 & 37,77 \\
\hline & ICBC Turkey Bank & 0,41 & 7,83 & 9,62 & 6,60 \\
\hline & HSBC Bank & 32,3 & 28,28 & 14,71 & 24,53 \\
\hline & Golden Global Bank & 0,03 & 2,52 & 6,64 & 3,34 \\
\hline & Deutsche Bank & 27,88 & 29,58 & 40,37 & 32,93 \\
\hline & Denizbank & 36,02 & 86,05 & 67,03 & 66,88 \\
\hline & Citibank & 56,02 & 48,10 & 21,20 & 40,66 \\
\hline & Burgan Bank & 0,69 & 3,36 & 18,90 & 8,13 \\
\hline & Alternatifbank & 4,2 & 7,98 & 59,43 & 25,04 \\
\hline
\end{tabular}

pdp=Popülerlik Değer Puanı, edp=Etkileşim Değer Puanı, idp=İ̧erik Değer Puanı

Tablo 12'deki Instagram değerlendirme endeks puanlarına göre; KMB kategorisinde Halk Bankası, KB kategorisinde Ziraat Katılım Bankası, ÖMB kategorisinde Türkiye İş Bankası ve YMB kategorisinde Garanti Bankası en yüksek değer puanına sahiptir. Bu bankaların takipçi sayıları, müşterilerle etkileşimleri ve içerik paylaşımları değerlendirildiğinde Instagram'1 etkin ve verimli bir şekilde kullandıkları söylenebilir. Kategorileştirilmemiş banka sıralamasında Türkiye'de Instagram'ı en etkin kullanan bankanın 88,36 IDE puanı ile İş Bankası olduğu; sıralamayı 86,14 IDE puanı ile Garanti Bankası, 82,47 IDE puanı ile Ziraat Katılım Bankası, 71,40 IDE puanı ile Halk Bankası'nın takip ettiği gözlenmiştir. Tablo 12'ye göre Halk Bankası'nın Türkiye sıralamasındaki yerini yükseltebilmesi için popülerlik parametre puanını başka bir ifadeyle Instagram hesabının takipçi sayısını artırması gerekmektedir. Sıralamadaki diğer bankalarla karşılaştırıldığında Halk Bankası'nın bu bankalara oranla takipçi sayısının az olduğu görülmektedir. Takipçi sayısını artıracak kampanyalar yapması endeks puanının yükselmesine olanak sağlayabilir.

Kuveyt Türk KB, kendi kategorisinde en yüksek popülerlik ve içerik değer puanına sahip olmasına rağmen etkileşim değer puanının düşük olmasından dolayı birinciliği Ziraat Katılım Bankası'na bırakmıştır. Instagram' 1 hedef kitleye ulaşmada bir araç olarak kullanmada çok fazla takipçiye sahip olma ve sürekli içerik paylaşımı yapma tek başına yeterli değildir. Etkin Instagram kullanımında takipçilerle/müşterilerle etkileşim önemli bir yere sahiptir. Golden Global Bank Yatırım, ICBC Turkey Bank ve Burgan Bank ise hem kendi kategorisinde hem de Türkiye sıralamasında en düşük endeks değer puanlarına sahip bankalardır. Bankaların popülerlik, etkileşim ve içerik değer puanları oldukça düşüktür. Bu bankaların aktif bir şekilde Instagram'da paylaşımda bulunmaması, takipçi sayısının az olması ve müşteriler ile karşılıklı etkileşimde bulunmamasından dolayı endeks puanları düşük çıkmıştır. 


\section{Sonuç ve öneriler}

Bu çalışma, Türkiye'deki mevduat ve katılım bankalarının hedef kitleye ulaşmak için Instagram'ı ne düzeyde kullandıklarını anlamaya hizmet etmektedir. Daha önce yapılmış çalışmalara benzer şekilde (Miranda vd., 2014, Göğüş, 2015), bu çalışma Miranda vd., (2013)'nin bankalar için geliştirdiği Facebook Değerlendirme Endeksi (FAI)'ni Instagram'a uyarlayan ilk çalışmadır. Çalışmada bankalar arası karşılaştırmalar yapılarak etkin Instagram kullanımında hangi stratejilerin etkili olduğuna dair öngörülerde bulunulmuştur. Finansal hizmet sağlayıcılarının sosyal medya kullanımına odaklanan önceki araştırmalarda, Facebook kullanımının banka finansal performansına etkisi (Nyambu, 2013; Malhatro, 2017; Konak ve Demir, 2018), çift yönlü müşteri iletişiminde (Chikandiwa, Contogiannis ve Jembere, 2013; Efma ve Capgemini, 2014; Ulaş, 2020), şikâyet yönetiminde (Güler, 2020) ve sosyal sorumluluk faaliyetleri ile ilgili paylaşımlarda (Süllü, 2019) Facebook ve Twitter kullanımı incelenmiştir. Işık vd., (2017) Türkiye' nin üç büyük bankasının Facebook kullanımlarını değerlendirirken; Kılıç (2017), BİST 30'da yer alan bankaların pazarlama iletişiminde Twitter kullanımını; Deniz vd., (2018) Türkiye' deki yabancı ve özel mevduat bankaların sosyal medya üzerinden çevrimiçi bankacıllk hizmeti sunma durumlarını incelemiştir. Ancak mevcut çalışma, Facebook ve Twitter sosyal medya platformlarına odaklanan yukarıda belirtilen çalışmaların aksine Türkiye'de faaliyet gösteren 30 mevduat ve katılım bankasının Instagram kullanımlarını ayrıntılı olarak inceleyip uyarlanmış bir endeks yardımıyla nicel veriler sunan ilk çalışmadır. Elde edilen bulguların, sosyal medya ve dijital pazarlama uzmanlarına rehberlik etmesi ve ileriki sosyal medya pazarlaması araştırmalarına yol göstermesi beklenmektedir.

Türkiye' deki mevduat ve katılım bankalarının Instagram kullanımlarına içerik analizi yapılmadan önce bankaların sosyal medya kullanımlarına yönelik ön bir araştırma yapılmıştır. Bu araştırmada bankaların web siteleri aracılığıyla resmi sosyal medya hesaplarına ulaşılmıştır. Yapılan incelemelerde mevcut araştırma kapsamındaki bankalardan sadece üçünün 2015 yılı öncesinde Instagram kullandığı; 2020 yılına gelindiğinde bu sayının 11 kat artarak 33'e yükseldiği tespit edilmiştir. Elde edilen bu bulgular, özellikle son dönemde çoğu bankanın Instagram hesaplarını, ürün/hizmet tanıtımı, marka farkındalığı, tutundurma ve diğer iş stratejileri için aktif bir şekilde kullandıklarını göstermektedir. Instagram, sosyal medya pazarlaması yapmak isteyen bankalar için güçlü bir pazarlama aracıdır. Çetinkaya ve Özdemir (2014)'in yaptıkları çalışma sonuçları ile uyuşmaktadır. Sosyal medya platformları, bankaların ürün ve hizmetlerinin etki alanını önemli ölçüde genişleterek tüketici tutum ve davranışlarını yönlendirebilmektedir (Jashari ve Rrustemi, 2017). Bu doğrultuda sosyal medya hesaplarının etkinliğini artıracak stratejilerin geliştirilmesi, bankaların dijital ortamdaki pazarlama faaliyetleri açısından önem taşımaktadır. Benzer bir şekilde Barutçu ve Tomaş (2013) sosyal medyada sürdürülebilir faaliyette bulunmanın işletme uygulamalarında başarı şansını artırabileceğini öngörmektedir.

Bu bağlamda mevcut çalışma ile Türkiye'deki bankaların Instagram kullanımlarını değerlendirmek üzere bir endeks oluşturulmuş ve endekste yer alan parametrelere ilişkin sonuçlar ve yorumlar sunulmuştur. Bankaların popülerlik parametresi değerlendirildiğinde Ziraat Bankası, Kuveyt Türk Katılım Bankası, Türkiye İş Bankası ve Türkiye Garanti Bankası' nın bulundukları kategorilerde en fazla takipçi sayısına sahip bankalar olduğu görülmüştür (Bkz. Tablo 2). İncelemeler sonucunda Kuveyt Türk Katılım Bankası dışındaki diğer üç bankanın 100.000'in üzerinde takipçisi olduğu ve bu bankaların takipçi sayılarını artırmak için çeşitli kampanyalar düzenlediği tespit edilmiştir. Ayrıca analiz edilen Instagram hesaplarının \%53,3'ünün 25.000'in üzerinde takipçisi olması Instagram'1 hedef kitle ile iletişimde önemli bir kanal haline getirmektedir. Öte yandan yabancı mevduat bankası kategorisindeki ICBC Turkey Bank, Golden Global Bank ve Burgan Bank'ın 1000 in altında takipçiye sahip olması, parametre değerlerinin sabit bir aralıkta olmadığının göstergesidir. Bu durum Instagram'ı müşteriye ulaşmada bir araç olarak kullanmaktan ziyade rakibin yaptığı hamleyi taklit etme ile açıklanabilir. Elbette ki izlenen bu yol araştırma sonuçlarının da desteklediği gibi başarılı olmayacaktır. Başarı için sosyal medya platformlarının, ürün ve hizmetlerle ilgili içerikleri hızlı ve etkili bir şekilde hedef kitleye ulaştırma ve böylece pazarlama ve reklam maliyetlerinde avantaj sağlama ayrıca esnekliği sayesinde dijital ortamdaki marka görünürlüğünü güncel tutma gibi avantajları unutulmamalıdır. Taşdemir (2011) çalışmasında sosyal medyanın bahsedilen avantajlarının bu platformların işletmeler tarafından hızlı bir şekilde benimsenmesinde etkili olduğunu belirtmiştir. Bu bağlamda popülerlik değer puanı yüksek olan bankalar, sürdürülebilir avantaj sağlayabilmek için, Instagram platformunun sunmuş olduğu istatistiki bilgileri sürekli olarak değerlendirilmeli ve ileriki stratejiler bu doğrultuda belirlenmelidir.

Instagram; ürün, hizmet ve kampanyalar hakkında bilgi vermenin yanı sıra, müşterilerle çift yönlü iletişim kurma ve müşteri katılımıyla (öneriler, şikayetler) yeni ürün ve hizmetler geliştirme olanağına 
sahiptir. Alan, Kabadayı ve Erişke (2018) çalışmalarında, sosyal medyada yapılan müşteri ilişkileri yönetiminin etkileşim ve etkin bir müşteri deneyimi yaratmaya olanak tanıdığını aynı zamanda bunun işletmenin müşterinin sesine cevap vermesi olarak görüldüğünü ifade etmişlerdir. Ticari amaç taşıyan paylaşımların aynı zamanda müşteri istek ve ihtiyaçlarıyla uyumlu ikna edici mesajlar içermesi, kullanıcı tutumlarının değişmesine ve farklı etkileşimlere neden olmaktadır. Göktaş ve Tarakçı (2018) çalışmalarında markaların Instagram'daki reklamlarının klasik tekniklere kıyasla daha dikkat çekici, akılda kalıcı ve diğer tüketicilerin o markanın gönderisini kendi profillerinde paylaşması durumunda satın alımda daha ikna edici olduğu sonuçlarına varılmışlardır. Instagram’da banka-müşteri etkileşimini ölçmek için ilk olarak bankaların son 7 gün içinde paylaştıkları duvar ileti sayısı belirlenmiştir. Bankalar haftada ortalama 4,8 ileti paylaşımı yapmıştır. Ancak araştırmaya dahil edilen bankaların \%50'si ortalama ileti sayısının altında paylaşımda bulunurken Garanti Bankası, Denizbank ve Vakıflar Bankası haftada 10'un üzerinde gönderi paylaşarak ilgili parametre puanında en yüksek puan alan bankalar olarak sıralamadaki yerlerini almışlarıdır (Tablo 3). Diğer etkileşim parametresi değerlendirme kriteri olan son on iletinin ortalama beğenilme sayısına bakıldığında İş Bankası'nın 2.686 üzerinde paylaşılan ileti başına beğeni sayısı bulunurken Golden Global Bank ve Turkish Bank'ın 50'nin altında paylaşılan ileti başına beğeni sayısına sahiptir. Bu sonuçlara göre İş Bankası' nın paylaşımları ile müşterilerini etkilediği söylenebilir. Paylaşılan ileti başına yorum sayısı değerlendirildiğinde bankaların \%33,3'ü 19'un üzerinde yorum alırken \%43,3'ü 3'ün altında yorum almıştır. 634 yorum sayısı ile İş Bankası en fazla yorum alan banka olmuştur. Son on iletiye yapılan müşteri yorumlarının bankalar tarafından cevaplanma durumları değerlendirildiğinde bankaların \%46,7'sinin kendilerine iletilen yorumları 24 saatten daha kısa bir sürede cevapladığı tespit edilmiştir. Müşteri yorumlarına cevap veren bankaların yapılan yorumları cevaplama oranlarına bakıldığında Ziraat Bankası ve Ziraat Katılım Bankası'nın \%19'un üzerinde cevaplama oranı bulunurken HSBC Bank kendisine iletilen yorumların sadece $\% 5,2$ 'sini cevaplamıştır.

Paylaşılan ileti sayısı, ileti beğenilme sayısı, yorum sayısı ve cevaplanan yorum sayısı kriterleri değer puanlarının ortalaması ile belirlenen nihai etkileşim değer puanına bakıldığında (Tablo 7) Halk Bankası (90), Ziraat Katılım Bankası $(88,88)$, Türkiye İş Bankası $(86,11)$ ve Türkiye Garanti Bankası $(88.75)$ bulundukları kategorilerde banka-müşteri etkileşimine en fazla önem veren bankalar olduğu görülmektedir. Vakıflar Bankası yüksek ileti ve beğenilme sayısına sahip olmasına rağmen gönderilerine yapılan yorum sayısının ve yorumlara cevap verme oranının düşük olmasından dolayı etkileşim parametresinde düşük değer almıştır. Daha sık paylaşım yapmak oldukça önemlidir. Hesaptaki beğenilerin, yorumların ve paylaşımların fazla olması tüketicilerin, yapılan paylaşımları daha çok gördüğünü ve bankanın tüketicilerle bir etkileşime girdiğini göstermektedir. Ancak, her bir gönderinin kaliteli bir gönderi olması gerekmektedir. Kötü içerikli paylaşım tüketiciler tarafından anında tepkiye ve banka hakkında kötü bir imaj oluşmasına neden olabilir. Bu nedenle gönderi programını tutarlı tutmak, başarı için önemlidir. Bu sonuçlarla benzer bir şekilde Yavuz (2019) çalışmasında, Instagram gönderilerinin kaliteli içeriğe sahip olmasının, beğeni ve yorum sayılarını artıracağını ve etkin kullanıcı etkileşiminin oluşacağını belirtmiştir. Ayrıca yüksek takipçi sayısı, yorum ve beğeniye sahip hesapların pozitif bir algı oluşturarak uzun vadede başarı sağlayacağını ifade etmiştir.

Bankalar içerik parametresi bağlamında değerlendirildiğinde Vakıflar Bankası (97,62), Kuveyt Türk Katılım Bankası $(100)$, Türkiye İş Bankası $(82,61)$ ve Türkiye Garanti Bankası $(73,28)$ kategorilerinde en yüksek içerik değer puanına sahip bankalardır. Bu bankaların multimedya öğelerini kullanarak finansal ürün ve hizmetler hakkında bilgi verdiğini, kampanyalar ve özel teklifler sunduğunu, sosyal duyarlılık etkinliklerini duyurduğunu ve tüm bunları yaparken Instagram'ı bir pazarlama aracı olarak kullandığını söylemek yanlış olmayacaktır. Ziraat Bankası'na kategorisindeki bankaları içerik parametresi özelinde yakalayabilmesi için video içerikli paylaşımlara ağırlık vermesi önerilmektedir. İçerik değer puanı düşük bankalara (Türkiye Emlak Katılım Bankası, Anadolubank, Golden Global Bank) çalışmada dikkate alınan içerik parametre kriterleri doğrultusunda paylaşımlarını geliştirmeleri tavsiye edilir. İncelemeler sonucunda, az sayıda ve yetersiz içerik paylaşıma sahip olan bankaların popülerlik ve etkileşim değer puanlarının da düşük olduğu gözlemlenmiştir. Yarışmalar, oyunlaştırma uygulamaları, özel teklifler içeren paylaşımlar hem etkili içeriklerin oluşmasına hem de takipçi sayısının artmasına olanak tanımaktadır. Beğenilen içerik paylaşımı sonucu artan takipçi sayısı, bankanın pazarlama mesajlarını iletebileceği hedef kitlesinin genişlemesini ve banka-müşteri ile müşteri-müşteri etkileşiminin artmasını sağlamaktadır. Yavuz (2019) yapmış olduğu çalışma ile bu sonuçları desteklemektedir.

Bankaları popülerlik, etkileşim ve içerik parametreleri bağlamında karşılaştırmalı olarak değerlendirdikten sonra nihai Instagram Değerlendirme Endeksi (IDE) sonuçları sunulmuştur. Endeks sonuçlarına göre İş Bankası 88,36 endeks puanı ile Türkiye' de Instagram üzerinden hedef kitle ile iletişim 
kurmada en başarılı banka olmuştur. Öte yandan Golden Global Bank'ın ise Instagram'ı hedef kitle ile iletişimde etkin bir araç olarak kullanmadığ 50 endeks puanının üzerinde, \%36,7'sinin 25-50, \%26,6'sının ise 3-25 arasında puan aldığ tespit edilmiştir. Bu sonuçlar bankaların çoğunun $(\% 63,3)$ Instagram'ı etkin bir şekilde kullanmadığını göstermektedir. Mevcut çalışma, Instagram'da etkin bir şekilde var olabilmek isteyen bankalara ipuçları sağlamaktadır. Bu ipuçları ile bankalar, rakiplerine göre güçlü ve zayıf yönlerini tespit ederek müşterileriyle olan iletişim ve ilişkilerini güçlendirebilirler. Müşterileri etkileyebilecek ve e-WOM yapmalarını sağlayacak kaliteli içerik paylaşımının, Instagram'ı finansal hizmetler sektöründe etkili bir pazarlama aracı olarak kullanabilmede önemli bir yeri bulunmaktadır. Bu bağlamda bankalar dinamik bir sosyal ağ olan Instagram' daki güncellemeleri sürekli takip etmeli ve stratejilerini bu güncellemelere göre uyarlamalıdır. İleriki bilimsel çalışmalarda, farklı sektör ve kültürlerde Instagram kullanımı mevcut çalışmada önerilen endeks yardımı ile değerlendirilebilir. Bu değerlendirme işletmelerin finansal performans göstergeleri ile karşılaştırılabilir.

\section{Hakem Değerlendirmesi / Peer-review:}

Diş bağımsız

Externally peer-reviewed

\section{Çıkar Çatışması / Conflict of interests:}

Yazarlar çıkar çatışması bildirmemiştir.

The authors have no conflict of interest to declare.

\section{Finansal Destek / Grant Support:}

Yazarlar bu çalışma için finansal destek almadığını beyan etmiştir.

The authors declared that this study has received no financial support.

\section{Yazar Katkıları / Author Contributions:}

Fikir/Kavram/Tasarım - Idea/Concept/Design: C.B, E.D., Veri Toplama ve/veya İşleme - Data Collection and/or Processing: C.B, E.D., Analiz ve/veya Yorum - Analysis and/or Interpretation: C.B Kaynak Taramas1 - Literature Review: C.B, E.D., Makalenin Yazımı - Writing the Article: C.B, E.D., Eleştirel İnceleme Critical Review: C.B, Onay - Approval: C.B, E.D.

\section{Kaynakça / References}

Ajina, A. S. (2019). The Role of Social Media Engagement in Influencing Customer Loyalty in Saudi Banking Industry. International Review of Management and Marketing, 9(3), 87-92.

Alan, A. K., Kabadayı, E. T. ve Erişke, T. (2018). İletişimin Yeni Yüzü: Dijital Pazarlama ve Sosyal Medya Pazarlamasi. Elektronik Sosyal Bilimler Dergisi, 17(66), 493-504.

Aldaihani, F. M. F. ve Ali, N. A. B. (2018). Impact of Social Customer Relationship Management on Customer Satisfaction through Customer Empowerment: A Study of Islamic Banks in Kuwait. International Research Journal of Finance and Economics, 170, 41-53.

Al-Kandari, A. A., Gaither, T. K., Alfahad, M. M., Dashti, A. A., ve Alsaber, A. R. (2019). An Arab Perspective on SSocial Sedia: How Banks in Kuwait Use Instagram for Public Relations. Public Relations Review, 45(3), 1-11. 
Anam, B., Sumbal, A., Marium, M. ve Sohail Y. (2017). The Impact of Corporate Social Responsibility (CSR) and Relationship Marketing on Relationship Maintainer and Customer Loyalty by Mediating Role of Customer Satisfaction. Journal of Management Info, 4(4), 12-18.

Arıkan, B. (2015). Türk Bankacılığında İnovasyon ve Kreatif Bankacılık. Yüksek Lisans Tezi, İstanbul Ticaret Üniversitesi, Sosyal Bilimler Enstitüsü, İstanbul.

Ateş, S. ve Karaduman, İ. (2019). Markanın Sosyal Medyadaki Takipçi Sayısı ve İçerik Miktarının Marka Değerine Etkisi. Stratejik ve Sosyal Araştırmalar Dergisi, 3(1), 163-179.

Ayre, C. ve Scally, A. J. (2014). Critical values for Lawshe's content validity ratio: revisiting the original methods of calculation. Measurement and Evaluation in Counseling and Development, 47(1), 79-86.

Bankacılık Alanında Önemli Bilgiler, Erişim Adresi: https://www.bankalar.org/ Erişim Tarihi: 25 Mart 2020.

Barutçu, S. ve Tomaş, M. (2013). Sürdürülebilir Sosyal Medya Pazarlaması ve Sosyal Medya Pazarlaması Etkinliğinin Ölçümü. İnternet Uygulamaları ve Yönetimi Dergisi, 4(1), 5-24.

Bhatti, A., Maraim ve Sumbal, A. (2017). The Impact of Social Media Mobile Advertising on Consumer Perception and Consumer Motivation by Considering Mediating Role as Brand Image and Brand Equity. International Conference on Management, Business \& Technology, Lahore, Pakistan. March 12$15,397-409$.

Bowen, G. A. (2009). Document Analysis as a Qualitative Research Method. Qualitive Research Journal, $9(2), 27-40$.

Chikandiwa, S.T., Contogiannis, E. ve Jembere, E. (2013). The Adoption of Social Media Marketing in South African Banks. European Business Review, 25(4), 365-381.

Chung, S., Animesh, A., Han, K. ve Pinsonneault, A. (2014). Firm's Social Media Efforts, Consumer Behavior, and Firm Performance. In: Proceedings of the 35th International Conference on Information Systems. Auckland, New Zealand. December, 14-17.

Çetinkaya, A. ve Özdemir, Z. (2014). Sosyal Ağların Pazarlama Disiplinleri İçinde Kullanımı: Instagram Üzerine Bir İnceleme. Dijital İletişim Etkisi Uluslararası Akademik Konferansı, İstanbul, 16-17 Ekim, 581598.

Deniz, R. B., Derici, S. ve Kılıç, E. (2018). Türkiye'de İnternet Bankacılı̆̆ı ve Sosyal Medya Platformlarında İnternet Bankacılığı Hizmeti Sunan Yerli ve Yabancı Mevduat Bankalarının Veri Zarflama Analizi (VZA) ile Etkinlik Ölçümü. Marmara Üniversitesi İktisadi ve İdari Bilimler Dergisi 40(1), 15-43.

Dijital 2020: Turkey, Erişim Adresi: https:// www.wearesocial.com/ Erişim Tarihi: 25 Mart 2020.

Efma ve Capgemini (2014). World Retail Banking Report 2021, Erişim Adresi: https://www.capgemini.com/world-reports/ Erişim Tarihi: 10 Haziran 2020.

Garanti, Z. ve Kissi, P.S. (2019). The Effects of Social Media Brand Personality on Brand Loyalty in The Latvian banking Industry: The Mediating Role of Brand Equity, International Journal of Bank Marketing, 37(6), 1480-1503.

Ginsberg, K. (2015). Instabranding: Shaping the Personalities of the Top Food Brands on Instagram. Elon Journal of Undergraduate Research in Communications, 6(1), 78-91.

Göğüş, H. (2015). Karşılaştırmalı Türkiye'deki Mevduat ve Katılım Bankalarının Sosyal Medya Kullanımına Yönelik Bir Değerlendirme: Facebook Değerlendirme Endeksi. Yüksek Lisans Tezi, Gaziantep Üniversitesi, Sosyal Bilimler Enstitüsü, Gaziantep.

Göktaş, B., ve Tarakçı, İ. E. (2018). Bir Tutundurma Aracı Olarak Reklamın Sosyal Medyada Uygulamalarına Yönelik Bir Araştırma: Instagram Örneği. Girişimcilik İnovasyon ve Pazarlama Araştırmaları Dergisi, 2(3), 50-67.

Gu, B., ve Ye, Q. (2014). First Step in Social Media: Measuring the Influence of Online Management Responses on Customer Satisfaction. Production and Operations Management, 23(4), 570-582.

Güler, H. N. (2020). Bankalara Sosyal Medya Üzerinden İletilen İletilerin İçerik Analizi ile İncelenmesi. Uluslararası Göbeklitepe Sosyal ve Beşeri Bilimler Kongresi, Şanlıurfa, 132-149. 
Ingbank (2013). Gençler Ödemelerini Sosyal Medya Aracılı̆̆ıyla Gerçekleştirmek İstiyor Basın Bülteni, Erişim Adresi:https://www.ing.com.tr/F/Documents/pdf/Basin_Odasi/2013/Gencler_Odemelerini_So syal_Medyadan_Yapmak_Istiyor_29062013.pdf/ Erişim Tarihi: 25 Mayıs 2020.

Işık, M., Karaca, M., İspir, İ., Çakı, G. ve Yıldırım, L.D. (2017). Sosyal Medya Platformlarının Halkla İlişkiler Amaçlı Kullanımı: Bankalar Üzerine İnceleme. Middle Black Sea Journal of Communication Studies, 2(2), 41-51.

Jashari, F., ve Rrustemi, V. (2017). The Impact of Social Media on Consumer Behavior-Case Study Kosovo. Journal of Knowledge Management, Economics and Information Technology, 7(1), 1-21.

Kaplan, A. M. ve Haenlein, M. (2010). Users of the World, Unite! The Challenges and Opportunities of Social Media. Business Horizons, 53(1), 59-68.

Kassarjian, H. H. (1977). Content Analysis in Consumer Research. Journal of Consumer Research, 4(1), 818.

Kaya, F (2012). Bankacılık Giriş ve İlkeleri. İstanbul, Beta Yayıncılık.

Kılıç, H. Ö. (2017). Bist 30' da Yer Alan Bankaların Pazarlama İletişiminde Twitter Kullanımının Analizi. İnsan ve Toplum Bilimleri Araştırma Dergisi, 6(6), 302-313.

Kiliç, S. (2015). Kappa testi. Journal Of Mood Disorders, 5(3), 142-144.

Konak, F. ve Demir, Y. (2018). Sosyal Medya Kullanımının Firma Performansına Etkisi: Türk Bankacıllk Sektörü Üzerine Bir Uygulama. VI. International Multidisciplinary Congress of Eurasia, Rome, Italy, September 4-6, 338-346.

Lawshe, C. H. (1975). A Quantitative Approach to Content Validity. Personnel Psychology, 28(4), 563-575.

Malhatro, P. (2017). Impact of Social Networking Sites on Financial Performance: A Case Study of Indian Banks. Eurasian Journal of Business and Economics, 2(4), 43-62.

Miranda, F. J., Chamorro, A., Rubio, S. Ve Morgado, V. (2013). Evaluation of Social Networks Sites in the Banking Sector: An Analysis of Top 200 International Banks. Journal of Internet Banking and Commerce, 18(2), 1-17.

Mitic, M. ve Kapoulas, A. (2012), Understanding the Role of Social Media in Bank Marketing, Marketing Intelligence and Planning, 30(7), 668-686.

Mousavi, J., Rad, H. S. ve Asayesh, N. (2015). The Effect of Social Media on Brand Loyalty. Bulletin of The Georgian National Academy of Sciences, 9(2), 16-21.

Nyambu, E. M. (2013). Influence of Social Media Marketing on Performance of Telecommunication Firms in Kenya. International Journal of Innovative Research and Development, 2(9), 184-190.

Parveen, F., Jaafar, N.I. ve Ainin, S. (2014). Social Media Usage and Organizational Performance: Reflections of Malaysian Social Media Managers. Telematics and Informatics, 32 (1), 67-78.

Rahmawati, T.Y., Dewi, M.K. ve Ferdian, I. R. (2019). Instagram: Its Roles in Management of Islamic Banks. Journal of Islamic Marketing, 11(4), 841-861.

Ramanathan, U., Subramanian, N., ve Parrott, G. (2017). Role of Social Media in Retail Network Operations and Marketing to Enhance Customer Satisfaction. International Journal of Operations and Production Management, 37(1), 105-123.

Schniederjans, D., Cao, E. S. ve Schniederjans, M. (2013). Enhancing Financial Performance with Social Media: An Impression Management Perspective. Decision Support Systems, 55(4), 911-918.

Stone, M. (2009). Staying Customer-Focused and Trusted: Web 2.0 and Customer 2.0 in Financial Services. Database Marketing and Customer Strategy Management, 16(2), 101-31.

Süllü, Z. (2019). Finansal Kuruluşların Sosyal Sorumluluk Faaliyetlerinde Sosyal Medya Kullanımı: Akbank, Garanti BBVA ve Türkiye İş Bankası A.Ş. Örneği. İnönü Üniversitesi İletişim Fakültesi Elektronik Dergisi, 4(2), 250-269.

Şakar, H. (2000). Genel Bankacıllk Bilgileri, İstanbul, Strata Yayıncılık.

Tajvidi, R. ve Karami, A. (2021). The Effect of Social Media on Firm Performance. Computers in Human Behavior, 115, 1-10.

Taşdemir, E. (2011). Bütünleşik Pazarlama İletişimde Sosyal Medya. Humanities Sciences, 6(3), 645-665. 
Tavşancıl, E. ve Aslan, E. (2001). Content Analysis and Application Examples, İstanbul, Epsilon Yayınları.

TBB (2020). Banka ve Sektör Bilgileri, Erişim Adresi: https:// www.tbb.org.tr/ Erişim Tarihi: 25 Mart 2020.

Ulaş, S. (2020). Marka İletişiminde Sosyal Medya ve Çevrimiçi Etkileşim (Online Engagement) İlişkisi: Limasol Türk Kooperatif Bankası Örneği. Manas Sosyal Araştırmalar Dergisi, 9(1), 274-285.

Vassallo, A. J., Kelly, B., Zhang, L., Wang, Z., Young, S. ve Freeman, B. (2018). Junk Food Marketing on Instagram: Content Analysis. JMIR Public Health and Surveillance, 4(2), 1-11.

Yavuz E. (2019). Instagram İçerik Tasarımlarının Grafik Tasarım Ögeleri Açısından İncelenmesi. İnönü Üniversitesi Uluslararası Sosyal Bilimler Dergisi (INIJOSS), 8(1), 321-328.

Yeşilyurt, S. ve Çapraz, C. (2018). Ölçek Geliştirme Çalışmalarında Kullanılan Kapsam Geçerliği için Bir Yol Haritası. Erzincan Üniversitesi Ĕ̆itim Fakültesi Dergisi, 20(1), 251-264.

Yurdugül, H. (2005). Ölçek Geliştirme Çalışmalarında Kapsam Geçerliği için Kapsam Geçerlik İndekslerinin Kullanılması. XIV. Ulusal Eğitim Bilimleri Kongresi Pamukkale Üniversitesi Eğitim Fakültesi, Denizli, 28-30 Eylül, 1-6. 